\title{
CLO Trading and Collateral Manager Bank Affiliation*
}

\author{
Stavros Peristiani and João A.C. Santos
}

First draft: January 2017

Current draft: February 2018

\begin{abstract}
This paper investigates whether the institutional affiliation of a collateralized loan obligation (CLO) manager influences the manager's access to information and risk appetite. We find that CLO managers affiliated with banks start to sell off their positions in loans arranged by their bank well before the onset of default. In contrast, CLO managers affiliated with nonbanks do not lower their exposures to distressed loans. These findings are consistent with bank-affiliated CLO managers being more risk averse, but they could also derive from them having access to valuable information. On close inspection, we find that although bank-affiliated CLO managers are averse to holding any distressed loans, they are also more aggressive at divesting distressed loans arranged by their parent bank, suggesting that they benefit from an information wedge. Besides helping us understand CLO managers' trading activities, our findings highlight a potential limit to banks’ ability to originate loans and distribute them via their affiliated CLOs.
\end{abstract}

Stavros Peristiani: Federal Reserve Bank of New York, 33 Liberty Street, Main 3, New York, NY, 10045 (e-mail: sc_peristiani@hotmail.com).

João Santos: Federal Reserve Bank of New York \& Nova School of Business and Economics, 33 Liberty Street, Main 3, New York, NY, 10045 (e-mail: joao.santos@ny.frb.org).

* The authors thank an anonymous referee, Anjan Thakor, Murillo Campello, Sergey Chernenko, and participants at the 2017 WFA-CFAR \& JFI conference "The Post-Crisis Evolution of Bank and Financial Markets" for valuable comments and suggestions. The views expressed in this paper are those of the authors and do not necessarily reflect the views of the Federal Reserve Bank of New York or the Federal Reserve System. 


\section{INTRODUCTION}

Securitization has considerably changed the intermediation of corporate credit with the advent of collateralized debt obligations (CDOs) and collateralized loan obligations (CLOs). Over time, banks increasingly used these structures to advance their “originate to distribute” approach to lending (Cetorelli and Peristiani 2012). The volume of securitization came to a halt during the financial crisis with the collapse of the subprime MBS sector. However, in contrast with nonagency MBS, CLO issuance has gradually recovered and remains a significant source of corporate credit funding. ${ }^{1}$

Despite the considerable volume of corporate loans outstanding in CLOs, we still know very little about the way CLO managers administer their loan portfolios. ${ }^{2}$ In this paper, we investigate whether the institutional affiliation of a CLO manager influences the manager's risk appetite and access to information. CLO managers typically have a "parent” financial institution. While managers affiliated with banks may be more risk conservative because their parent organizations are less risk prone by virtue of being subject to prudential regulation and supervision, we are particularly interested in finding out whether an affiliation with a bank that arranges loans in the syndicated loan market is a source of valuable information for the CLO manager.

All syndicate participants, including CLOs, receive borrower information on a regular basis describing their financial performance and covenant compliance. However, loan arrangers, tasked with monitoring the borrower, compile useful private financial information throughout the duration of their relationship with the borrowing firm (Petersen 2004). Therefore, CLO managers affiliated with banks may have access to private information with regard to their investments in those loans that were arranged by their affiliated bank.

\footnotetext{
${ }^{1}$ The recent rebound of CLO issuance is discussed more extensively in Peristiani and Santos (2015).

${ }^{2}$ As of the second quarter of 2016, the outstanding volume of CDOs issued in the United States was about $\$ 650$ billion (SIFMA).
} 
We investigate that premise by analyzing CLO managers' trading activity in the year leading up to their default. We focus on trading during this time period because private information is more valuable during turbulent periods, and as we will see, there is a significant price decline in the secondary loan market during the year leading up to the loan default.

We start by identifying CLO managers affiliated with banks that are lead arrangers in the syndicated loan market. We also consider other potential tiers of private information stemming from syndicate participations or the CLO underwriter. Since CLO underwriters can also serve as syndicate lead arrangers, they can potentially act as an alternative channel of private information to CLO managers. The flow of information from an underwriter, however, is unlikely to be as strong as that from the CLO parent bank when the two entities are not part of the same organization.

We classify all CLOs' loan positions into four mutually exclusive types of relationship to the CLO manager: (1) arranger relationship: loans arranged by the bank that is affiliated with the CLO manager, (2) underwriter relationship: loans arranged by the CLO underwriter, (3) participant relationship: loans participated in by the CLO manager/parent or its underwriter, and (4) no relationship: loans neither arranged by nor participated in by the CLO manager or its underwriter.

Our regression results reveal no significant decrease in CLO managers' holdings of distressed no-relationship loans and only minor changes in CLOs’ holdings with indirect relationships with the arranger of distressed loans. In contrast, CLO managers affiliated with the arrangers of the distressed loans start to sell off their positions well before the onset of default.

These results are robust. They continue to hold when we include CLO fixed effects in addition to borrower fixed effects, and when we restrict our analysis to defaulting loans held only 
in the portfolios of CLOs affiliated with loan arrangers, an approach that mitigates sample selection bias. They also remain unchanged when we limit the sample to single-loan positions to reduce the potential mismatch of aggregating multiple loan securities for a given borrower. Further, our empirical findings are robust to different time windows around the event of default.

Our evidence that CLO managers affiliated with arrangers of distressed loans start to sell off their positions well before the onset of default is consistent with the idea that this affiliation provides access to valuable information. However, because these affiliations are predominantly with banks, which are the dominant arrangers in the syndicated loan market, this finding raises the prospect of an alternative explanation. If CLO managers affiliated with banks are more sensitive to risk, they would be more likely to dispose of distressed assets. Implicit in this idea is the assumption that such an association could expose the parent organization to scrutiny, thereby compromising its brand and ability to market securities to institutional clients (Brown 2007). The parent organization could also face several perils from badly performing CLOs: litigation risks, regulatory risks, negative investor reaction, and loss of business from clients. These problems are likely exacerbated in the case of parent banks because of their low-risk appetite given they are subject to prudential regulation and supervision.

We attempt to disentangle the importance of private information and institutional factors. We start by comparing the pre-default trading of bank-affiliated and nonbank-affiliated CLO managers on borrowers that they have no loan relationships with, thus removing privateinformation biases. In this case, bank and nonbank affiliated CLO managers essentially depend on available public sources and syndicated loan reports provided by an unaffiliated lead arranger. Although they use similar information, we find that bank-affiliated CLO managers are more active in selling distressed loans, adding to the idea that bank-affiliated CLO managers are more risk conservative. 
To ascertain whether there is a separate information effect, in our final test we compare CLO managers' trading on distressed loans arranged by their affiliated bank with their trading on distressed loans arranged by other banks. This comparison reveals that CLO managers are more proactive in divesting their banks' arranged distressed loans than other unaffiliated arranged distressed positions. This result adds important support to the thesis that CLOs affiliated with banks gain access to valuable information on the loans arranged by their parent institutions. This finding is important for yet another reason: it reduces concerns that the differences in CLOs' loan positions over time that we unveil derive from differences in loan valuations as opposed to trading activity.

Despite the critical role that CLOs play in corporate loan securitizations, researchers to date have paid limited attention to the management of these financial vehicles and focused instead on other issues. ${ }^{3}$ The paper in the literature closest to ours is probably Lou, Loumioti, and Vasvari (2014), which examines the influence of private information on CLO performance. Their findings suggest that CLO managers have access to private information that they use to trade strategically to boost performance. Lou et al. infers whether CLO managers have access to private information through a proxy variable computed from a model that attempts to control for all available public information sources of loan trading. In contrast, we rely on the affiliation of CLO managers with banks to ascertain whether they have access to private information.

In addition, we consider the importance that bank-specific factors, such as their franchise value, may have on their affiliated CLOs. In this regard, our paper shares some similarities with Chernenko (2017). Using a large sample of ABS CDOs issued during 2002-2007, Chernenko finds that specialized CDO managers invested in low quality securities underwritten by the

\footnotetext{
${ }^{3}$ These include the rapid growth of CLOs (Bord and Santos 2012; Guo and Zhang 2015), the impact of securitization on the cost of bank credit (Nadauld and Weisbach 2014 and Bord and Santos 2015), the performance of securitized corporate loans (Shivdasani and Wang 2011; Benmelech, Dlugosz and Ivashina 2012; Bord and Santos 2015 ), and the ability of borrowers to renegotiate their loans (Paligorova and Santos 2016).
} 
CDO's arranger and were rewarded with additional collateral management assignments. In contrast, diversified CDO managers did not engage in such practices, possibly out of concern with the franchise value of their other businesses. Like Chernenko, we are interested in the importance of affiliations for managers of securitization vehicles. His focus is on ascertaining whether reputational concerns lead diversified CDO managers to make better investment decisions. We too consider the impact that the reputation of the parent institution may have on affiliated CLOs, but our focus is on ascertaining whether an affiliation with a bank active in the syndicated loan market is a source of valuable information for the CLO manager.

Finally, our paper is related to those studies, including Massoud et. al (2009), Ivashina and Sun (2011) and Bushman, Smith, and Wittenberg-Moerman (2011), which have documented that investors use the private information they obtain while participating in the syndicated loan market to trade in other markets. Our paper expands this literature by focusing on CLO managers, an increasingly important player in the syndicated loan market.

The remainder of the paper is organized as follows. Section 2 details the motivation for our analysis and lays out our hypothesis. Section 3 presents our data and methodology and describes the CLO sample. Sections 4-5 report and discuss our findings on the impact of CLO managers' affiliation with banks on their trading activities in the year leading up to borrower default. Section 6 concludes with some final remarks.

\section{MOTIVATION AND HYPOTHESES}

The key player in a CLO structure is the collateral manager (or CLO manager), who is tasked with assembling the CLO portfolio and managing collateral risks throughout the life of the CLO. The collateral of a cash-flow CLO consists mainly of business loans (syndicated term loans), but it may include a small fraction of corporate bonds and other asset-backed securities. 
During the buildup phase, the CLO manager enlists an underwriter (CLO underwriter), who takes on the traditional responsibilities of assessing investor interest, selling the securities, and providing liquidity support. The underwriter may also facilitate the buildup of the portfolio by offering the manager the option of purchasing loans from a warehouse facility, a purchase often financed with a bridge credit arrangement. The underwriter, in turn, engages a rating agency to determine the seniority tranche structure of the deal and issues the securities (CLO notes and an equity tranche) to investors. The seniority guidelines of the CLO specify how proceeds from principal and interest payments are distributed.

After the ramp-up period, the CLO enters the reinvestment phase, which is followed by amortization. During the reinvestment phase, which ranges from 3 to 5 years, CLO managers reinvest interest proceeds and principal repayments; they also trade assets to realize capital gains, take advantage of good investment opportunities, or avoid potential credit risks. In the amortization period, the cash flows are used mainly to pay down the security notes.

CLO managers usually receive a fixed management fee plus a contingent fee paid only after the equity tranche achieves a certain hurdle rate. ${ }^{4}$ The latter fee incentivizes managers to deliver a minimum level of returns to the investors in the equity tranche.

CLO managers are bound by a number of operational constraints. In general, they can trade only up to 20 percent of the portfolio's par value each year. They must also meet certain compliance tests (for instance, an overcollateralization asset-liability threshold) and covenants established to protect investors. However, CLO managers appear to have developed ways to circumvent some of these rules. For instance, Loumioti and Vasvari (2016) note that, to avoid

\footnotetext{
${ }^{4}$ The manager receives a portion of its fixed fee before the most senior tranche of debt receives a return or is paid, and it receives the remainder of the fee after the debt tranches are paid but before the equity tranche is paid.
} 
violating overcollateralization requirements, CLO managers often inflate the fair market value of loan assets and prefer to rebalance their portfolio by selling high-quality assets.

Finally, CLO managers are usually affiliated with a bank or a nonbank financial institution such as a hedge fund, private equity firm, or insurance firm. As we argue below, the type of institution the CLO manager is affiliated with is important because it may affect the information available to the manager and possibly its risk-taking incentives.

\subsection{The Effect of Affiliation on Availability of Information}

Arrangers in the syndicated loan market are responsible for collecting detailed financial information on borrowing firms and for monitoring their compliance with covenants, including their financial performance obligations, and they are expected to regularly share that information with syndicate members.

Arrangers also have access to additional information on borrowers that is not shared with other syndicate members. As noted by Petersen (2004), arrangers gather a good deal of private qualitative information—personal observations, evaluations, viewpoints, and opinions compiled by the borrowers' loan officers over the length of the lender-borrower relationship. This information is important to the understanding of large, complex entities as well as to the evaluation of smaller, less transparent firms. But as "soft," impressionistic information, it is difficult to transfer to other parties and therefore has the potential to create an informational wedge between arrangers and syndicate participants.

The relationship between borrowers and lenders is bound by confidentiality agreements. For example, the monthly financial loan disclosures, projections, and other financial information certifying the borrower is compliant must remain out of the public domain. ${ }^{5}$ However, the rapid

\footnotetext{
${ }^{5}$ In the case of bonds issued by public firms, information about the bonds is eventually disclosed in reports to regulators.
} 
growth of the secondary loan market over the past decade has attracted nonbank and unregulated investors and blurred the limits on the disclosure of private information.

This changing landscape of the syndicated loan market has significantly altered the diffusion of information among market participants. A 2011 report by Standard and Poor's highlighting a rise in loan price volatility in the secondary market supports anecdotal evidence that nonbank syndicate participants trade on private information. A number of academic studies also find empirical support for that assertion. For example, Bushman, Smith, and Wittenberg-Moerman (2011) find that price discovery is faster in loans with covenant violations (which are disclosed to syndicate members) and document a stock price reaction to these private disclosures. Massoud et. al (2009) argue that investors benefit from using insider information obtained from participating in syndicated loan activities and renegotiations.

When CLO managers invest in a loan they will gain access to the financial reports available to all members of the syndicate. Further, because loan arrangers have access to additional proprietary borrower information, it follows that CLO managers affiliated with loan arrangers may also be privy to that unique information, which they can use to enhance their trading activities. This gives us our main testable hypothesis:

Hypothesis 1: CLO managers affiliated with loan arrangers have access to private information.

\section{METHODOLOGY, DATA, AND SAMPLE CHARACTERIZATION}

\subsection{Methodology}

We attempt to ascertain whether CLO managers affiliated with loan arrangers gain access to private information by investigating their trading activity around the time of loan defaults. The default event offers us a good opportunity to investigate our hypothesis because it triggers the 
release of important information on borrowers. Figure 1 documents the change in price for defaulted loans traded in the secondary loan market. ${ }^{6}$ The figure traces the average loan price 250 trading days before and after default for a balanced sample. To facilitate the comparison across loans, we normalize the price at the time of default $(t=0)$ to equal 100 . As we can see from the figure, there is a monotonic decline in the secondary loan prices of distressed loans up until the event of default at which time loan prices appear to stabilize, highlighting the importance of trading in the period leading up to the default.

The next step in our methodology is the definition of a measure of CLO trading activity. Let $\mathrm{P}_{\mathrm{tij}}$ denote CLO (j) investment in loan (i) at month (t), with the monthly time indicator ranging from $t=0$, the origination month, until T. A common measure of trading activity for loan (i) is given by the change in holdings, or $\Delta \mathrm{P}_{\mathrm{tij}}$, representing month-to-month changes. ${ }^{7}$ A better estimate of the cumulative trading activity is given by $R_{t i j}=P_{t i j} / P_{0 i j}$, where $P_{0 i j}$ represents the initial investment. We formally refer to $R_{t i j}$ as the investment ratio of CLO (j) in loan (i) at month (t). ${ }^{8}$ We set the investment ratio at 100 percent at $(\mathrm{t}=0)$.

Finally, we use a straightforward regression specification to analyze CLO managers' trading around default. We assume that a CLO investment ratio in a borrower $\mathrm{R}_{\mathrm{tij}}$ is a function of the borrower characteristics, the structure of the CLO, and a set of CLO-manager-specific factors. More precisely, we use the following trading model:

$$
\mathrm{R}_{\mathrm{tij}}=\alpha_{\mathrm{t}}+\alpha_{\mathrm{i}}+\beta_{1} \mathrm{x}_{\mathrm{tij} \bullet}^{\mathrm{B}}+\beta_{2} \mathrm{x}_{\mathrm{tij}}^{\mathrm{CLO}}+\sum_{\mathrm{h}=-\mathrm{H}}^{\mathrm{H}} \delta_{\mathrm{h}}^{\mathrm{M}} \operatorname{Rel}_{\mathrm{tij}, \mathrm{h}}^{\mathrm{M}}+\sum_{\mathrm{h}=-\mathrm{H}}^{\mathrm{H}} \delta_{\mathrm{h}}^{\mathrm{P}} \operatorname{Rel}_{\mathrm{tij}, \mathrm{h}}^{\mathrm{P}}+\sum_{\mathrm{h}=-\mathrm{H}}^{\mathrm{H}} \delta_{\mathrm{h}}^{\mathrm{U}} \operatorname{Rel}_{\mathrm{tij}, \mathrm{h}}^{\mathrm{U}}+\sum_{\mathrm{h}=-\mathrm{H}}^{\mathrm{H}} \delta_{\mathrm{h}}^{\mathrm{N}} \operatorname{NORel}_{\mathrm{tij}, \mathrm{h}}+\varepsilon_{\mathrm{tij}}
$$

\footnotetext{
${ }^{6}$ We thank Pei Shao for providing us with the pricing information on defaulted loans from LSTA used in Figure 1.

${ }^{7}$ CLO managers also invest a small fraction of their portfolio in corporate bonds and other asset-backed securities. Our analysis, however, focuses only on the more important loan assets.

${ }^{8}$ We explored alternative measures of trading activity, such as the simple change $\Delta \mathrm{P}_{\mathrm{tij}}$ and $\mathrm{R}_{\mathrm{tij}}=\sum_{\mathrm{t}} \Delta \mathrm{P}_{\mathrm{tij}} / \mathrm{P}_{0 \mathrm{ij}}$. Overall, the regression analysis results were very similar.
} 
The vector $\mathrm{x}_{\mathrm{tij}}^{\mathrm{B}}$ includes publicly available borrower-specific variables that vary over time such as the borrower's monthly credit rating, while the vector $\mathrm{x}_{\mathrm{t} \mathbf{t}^{\circ}}^{\mathrm{CLO}}$ includes CLO-specific explanatory variables, such as the size of the CLO facility. In a number of specifications, the vector $\mathrm{x}_{\mathrm{t} \mathbf{0}}^{\mathrm{CLO}}$ is replaced by CLO fixed affects. The controls $\alpha_{t}$ and $\alpha_{i}$ represent year and borrower fixed effects, respectively.

Key to our analysis is the set of dummy variables we specify to identify whether the CLO manager has a relationship with the various sources of information on borrowers of defaulting loans (h) months from the time of default. For simplicity, we assume that $h=-H, \ldots, 0, \ldots, \mathrm{H}$, where $(h=0)$ represents the month of the default event. We consider three possible sources of affiliated proprietary information, represented by $\operatorname{Rel}_{\mathrm{tij}, \mathrm{h}}^{\mathrm{M}}$, $\operatorname{Rel}_{\mathrm{ti \textrm {i } , \mathrm { h }}}^{\mathrm{P}}$ and $\operatorname{Rel}_{\mathrm{ti \textrm {i } , \mathrm { h }}}^{\mathrm{U}}$. The dummy variable $\operatorname{Rel}_{\mathrm{tij}, \mathrm{h}}^{\mathrm{M}}$ indicates whether the CLO manager is affiliated with the arranger of the defaulting loan, $\operatorname{Rel}_{\mathrm{tij}, \mathrm{h}}^{\mathrm{U}}$ indicates whether the CLO underwriter was the arranger of the defaulting loan, and $\operatorname{Rel}_{\mathrm{tij}, \mathrm{h}}^{\mathrm{P}}$ controls for whether the CLO underwriter or the CLO manager were participants in the syndicate of the defaulting loan at the time of the loan origination.

Arguably, the indicator $\operatorname{Rel}_{\mathrm{tij}, \mathrm{h}}^{\mathrm{M}}$ captures the instances in which the CLO manager can obtain the most insightful and valuable soft information about the borrower. The two other possible relationships, $\operatorname{Rel}_{\mathrm{tji}, \mathrm{h}}^{\mathrm{U}}$ and $\operatorname{Re}_{\mathrm{t} \mathrm{j}, \mathrm{h}}^{\mathrm{P}}$, represent the intermediate case in which the CLO manager could get access to loan information through indirect channels.

We complement these variables with the dummy variable $\mathrm{NORel}_{\mathrm{tij}, \mathrm{h}}$, which captures the cases where the CLO manager (and its bank underwriter) neither is affiliated with the arranger of 
the defaulting loan nor was a participant in the loan syndication. In this case, the CLO manager only receives the reports from an unaffiliated arranger after it starts its investment on the loan. ${ }^{9}$

That set of indicator variables, together with the parameter estimates of $\delta_{\mathrm{h}}^{\imath}$, tells us the incremental change in the investment ratio (h) months before the event of default by the corresponding information relationship group (1). For example, a value of 5 for $\delta_{\mathrm{h}}^{\mathrm{l}}$ corresponds to a 5 percent increase from the initial $(\mathrm{t}=0)$ position; the actual change from, say, a 140 percent investment ratio at month $(\mathrm{h}-1)$ is $5 / 140$, or 3.57 percent.

We consider two testable predictions from our hypothesis that CLO managers affiliated with loan arrangers gain access to more information and therefore are better able to respond to distress before default:

HYPOTHESIS 1A: CLO managers affiliated with the arranger of the defaulting loan are able to divest from that loan before default. This premise can be statistically tested by maintained hypothesis $\mathrm{H}_{0}: \bar{\delta}_{\mathrm{B}}^{\mathrm{l}} \leq 0$, where $\bar{\delta}_{\mathrm{B}}^{\mathrm{l}}=\left[\sum_{\mathrm{h}=-1}^{-\mathrm{H}} \delta_{\mathrm{h}}^{\mathrm{l}} / \mathrm{H}\right]$ such that $\mathrm{\imath}=\mathrm{M}, \mathrm{U}, \mathrm{P}$.

HYPOTHESIS 1B: The sell-off before default of distressed loans by CLO managers affiliated with the arranger of that loan is greater than the sell-off by remaining CLO managers. We test this premise by $\mathrm{H}_{0}: \bar{\delta}_{\mathrm{B}}^{\mathrm{M}} \leq \bar{\delta}_{\mathrm{B}}^{\mathrm{U}}, \mathrm{H}_{0}: \bar{\delta}_{\mathrm{B}}^{\mathrm{M}} \leq \bar{\delta}_{\mathrm{B}}^{\mathrm{P}}$ or $\mathrm{H}_{0}: \bar{\delta}_{\mathrm{B}}^{\mathrm{M}} \leq \bar{\delta}_{\mathrm{B}}^{\mathrm{N}}$.

\footnotetext{
${ }^{9} \mathrm{CLO}$ managers typically purchase a loan from a warehouse facility or from the secondary market. Once the loan is added to the CLO portfolio, the collateral manager becomes a member of the syndicate and is qualified to receive monthly reports and updates detailing the borrower's financial condition and capacity to meet loan covenant conditions. There is, however, a subtle difference between $\operatorname{NORel}_{\mathrm{tij}, \mathrm{h}}$ and $\operatorname{Rel}_{\mathrm{tij}, \mathrm{h}}^{\mathrm{P}}$. In the case of $\operatorname{NORel}_{\mathrm{tij}, \mathrm{h}}$ the source of information stems from customary reports available to all syndicate members (including $\operatorname{Re}_{\mathrm{tij}, \mathrm{h}}^{\mathrm{P}}$ ) throughout the life of the loan. In the case of $\operatorname{Rel}_{\mathrm{tij}, \mathrm{h}}^{\mathrm{P}}$, CLO managers could gain additional insights because they are affiliated with an entity that participated in multiple loan syndicates.
} 
We complement the investigation of these predictions with a series of tests which aim at ascertaining alternative explanations for our findings, in particular the possibility that bankaffiliated CLO managers are more risk conservative.

\subsection{Data Sources}

To investigate our hypotheses regarding the impact of CLO managers' affiliations on their trading decisions, we start by gathering information from Moody's CDO Services database on the composition of CLO investment portfolios over time.

The Moody's database reports portfolio positions compiled from monthly trustee reports. Because this database does not contain unique loan security identifiers, we aggregate all CLO portfolio security positions at the borrower level. This does not significantly alter the structure of portfolios because nearly 80 percent of the CLO positions have only one investment per borrower. This aggregation gives us the opportunity to trace in a consistent way the changes in the CLOs’ total notional value invested in each borrower over time. ${ }^{10}$

The Moody’s database also provides extensive information on CLO managers and underwriters. This information is critical for our goal of understanding the impact of the relationships between the CLO manager and other players in the securitization chain. We complement these data with information from Capital IQ and Dealscan to ascertain the nature of the relationship between the CLO manager and the members of the syndicate in each loan in the CLO portfolio of collateral.

\subsection{Sample Characterization}

\footnotetext{
${ }^{10}$ Collateral managers often swap loan securities from the same borrower. Sometimes the replacement results from an exchange, redemption, or restructuring and is thus nondiscretionary. In other instances, however, managers may prefer a security from the same borrower with better features, such as longer duration and higher seniority. None of these security replacements contribute to turnover in our borrower-specific information.
} 
Our sample consists of 239 CLOs originated between 2007 and 2011 as arbitrage cash flow or small- to medium-market CLOs. ${ }^{11}$ We exclude synthetic transactions that derive their cash flow from credit default swaps and are therefore not actively managed. The average original face value of the sample CLOs is $\$ 485$ million (Table 1). Our CLOs are invested in more than 5,000 borrowers with about 65,000 unique CLO-borrower positions. The overall number of observations in the CLO-borrower panel is about 1.47 million.

CLO managers are affiliated with five broad categories of financial institutions: banks, insurance firms, hedge funds, private equity firms, and investment asset-manager firms. Table 1 reveals a significant heterogeneity among CLO managers. Importantly for our purposes, 55 of the 239 CLO managers are affiliated with banks. Equally important, a default occurs during the sample period (2007-11) in more than 20 percent of the borrowers in which the CLOs invest. ${ }^{12}$

Figure 2 shows CLO managers' trading activity over the first four years of the CLO's life. During the ramp-up period (the first six months), the investment ratio varies significantly for all types of managers' affiliations. Recall that, by definition, the investment ratio is 100 percent at $(\mathrm{t}=0)$. The greater variance during the ramp-up period is not unusual because managers are building up their portfolios from scratch. To exclude the initial trading volatility and its impact on $\mathrm{R}_{\mathrm{tij}}$, we omit the ramp-up phase of trading in our regression analysis.

As we can see from Figure 2, CLO managers continue to trade actively well beyond the ramp-up period, with the average investment ratio slowly rising from around 110 percent at $t=18$

\footnotetext{
${ }^{11}$ Small- to medium-market CLOs are a minor specialized segment of structured corporate debt products typically backed by loans to small and medium-size enterprises.

${ }^{12}$ We use information from several sources to ascertain corporate default. The trustee reports compiled by Moody's identify borrowers that defaulted. In addition, Moody's separately provides its own assessment of whether a borrower defaulted. We complemented these main sources of default information by identifying (1) distressed borrowers assigned a D rating by any credit rating agency and (2) firms that filed for bankruptcy (Capital IQ). As a final check, we manually investigated the entire sample of borrowers using Capital IQ's corporate timeline to verify the sequence of insolvency events. The onset of firm distress is defined as the first occurrence of insolvency reported in the trustee reports, the Moody's database, and bankruptcy information.
} 
to around 140 percent at $t=36$. The trading pattern naturally varies over the CLO lifecycle. ${ }^{13}$ For a sample of arbitrage cash-flow CLOs similar to the present sample, Peristiani and Santos (2015) estimate the average monthly buying turnover (relative to assets) over the 2007-11 period to be about 5.5 percent (corresponding to a 66.5 percent annual rate). After the ramp-up period, managers become more active sellers as they seek to replace some of the original temporary holdings. Importantly, although part of the position turnover stems from loan repayments and renegotiations, most of the buying and selling is discretionary.

Table 2 summarizes the control variables of our regression analysis. As noted earlier, a small portion of the collateral in a typical cash-flow CLO consists of corporate bonds and occasionally other structured securities. Given the focus on evaluating the importance of private syndicate information, we restrict the analysis to loan positions, which constitute the bulk of the collateral. The average investment ratio for the regression sample is about 137 percent. In some extreme cases, in which the initial holdings are very small, the investment ratio can be much larger. We mitigate the impact of these outliers by winsorizing the investment ratio, as well as other explanatory variables in the regression, at the $1^{\text {st }}$ and $99^{\text {th }}$ percentiles.

The average position in each borrower is around $\$ 3.81$ million, with the $99^{\text {th }}$ percentile at \$25.75 million. The relatively small nominal positions and narrow range show that CLOs are well diversified. Indeed, on average, they hold investments in about 160 borrowers. The median volume-weighted maturity in our sample of loans is 4 years. About 95 percent of the borrowers in the portfolios are domiciled in United States(US_FIRM). Finally, the average borrower credit rating is $\mathrm{B}+$. This masks the true credit quality risk because more than 47 percent of the borrowers fall in the range of $\mathrm{B}+$ to $\mathrm{B}-$.

\footnotetext{
${ }^{13}$ In theory, a CLO with fully invested proceeds must sell securities in its portfolios to reinvest. Typically, before CLOs enter the reinvestment period, CLO buying precedes selling as collateral managers accumulate positions.
} 
The bottom panel of Table 2 summarizes the relationships between the CLO manager, its underwriter, and the borrowing firm for each loan in the CLO portfolio. Close to 67 percent of CLO borrowers have no affiliation with either the manager or underwriter because typically the portfolios are compiled from various loan warehouse facilities; moreover, a lot of the CLO collateral consists of smaller low-rated firms with a limited history of syndicated loan issuance. The remaining segment of borrowers, however, has an information relationship with the manager or the underwriter of the CLO allowing us to empirically test our maintained hypotheses.

CLO underwriters were the arrangers in 11 percent of the loan investments in our sample. For 19 percent of the investments the CLO manager has a relationship only via its participation in the syndicate or via the participation of its underwriter $\left(\operatorname{Rel}_{t \mathrm{ji}, \mathrm{h}}^{\mathrm{p}}\right)$. CLO managers have the most informative link with borrowers when they are affiliated with the arranger of the loan, which occurs for 3 percent of the CLO investments.

Table 3 decomposes the sample of CLO-borrower holdings for the subset of firms that defaulted by the type of manager, which forms the basis of our regression sample. This table reveals that the small fraction loans with arranger relationships $\left(\operatorname{Rel}_{\mathrm{tij}, \mathrm{h}}^{\mathrm{M}}\right)$ is dominated by banks that are responsible for nearly 94 percent of these syndicated loans.

\section{DETERMINANTS OF CLO TRADING}

The regression model defined by equation (1) outlines several determining factors for the trading activities of CLO managers; our primary focus, however, is on their affiliation with arrangers of loans around their default date. One way to estimate equation (1) is to use the entire panel encompassing all CLO $\times$ borrower observations for all possible monthly observations before and after default. This approach is not very practical because the monthly panel of distressed borrowers is distributed asymmetrically around default. For example, in about 10 
percent of the borrower defaults, CLOs have no previous exposure to the borrower; rather, in those cases, the CLO manager purchased the loan after the borrower defaulted. These uneven investment patterns introduce sample-selection biases because the investment strategies of managers before default would differ from those after default.

To better balance these investment incentives, we start by focusing on defaults for which CLOs had a minimum of 6-months' investment history before the default date. A potential concern with this time horizon is that it leaves out investments for which CLOs sold off their entire positions before the 6-month date. This is a valid concern because as we saw in Figure 1, loan prices start to decline more than 6 months ahead of the default date. To address this concern, we also investigate a fully balanced sample focusing on defaults for which a CLO manager had purchased the loan a minimum of 12-months before the default date.

\subsection{Testing Hypothesis 1: The Importance of Private-Information Relationships}

We begin with a graphical overview of CLO managers' responses to borrower distress, that is, the in-sample regression investment-ratio predictions for the loan-relationship alternatives (Figure 3). This graphical evidence tracing the response to private information offers a useful summary of CLO managers' trading activities around default.

The investment ratio forecast for the relationship between the loan arranger and the CLO manager is calculated for the average borrower in the sample, defined more formally as $\hat{\mathrm{R}}_{\mathrm{h}}^{\mathrm{l}}=\bar{\alpha}_{\mathrm{i}}+\bar{\alpha}_{\mathrm{j}}+\bar{\alpha}_{\mathrm{t}}+\hat{\beta}_{1} \overline{\mathrm{x}}^{\mathrm{B}}+\hat{\beta}_{2} \overline{\mathrm{x}}^{\mathrm{CLO}}+\hat{\delta}_{\mathrm{h}}^{\mathrm{l}}=\hat{\mu}+\hat{\delta}_{\mathrm{h}}^{\mathrm{l}}$. The estimates $\bar{\alpha}_{\mathrm{i}}$ and $\bar{\alpha}_{\mathrm{t}}$ represent the average regression for borrower fixed-effects and time effects, respectively. The first five components of the investment ratio forecast represent the average-response baseline $\hat{\mu}$; the extant impact of the private-information relationships is determined by the corresponding $\hat{\delta}_{\mathrm{h}}^{\mathrm{l}}$ deviation coefficients. 
As we can see from Figure 3, when CLO managers have no relationships with defaulting borrowers $\left(\right.$ NORel $_{\mathrm{tij}}=1$ ), there does not appear to be any significant trading during the year leading up to the default. For CLO managers with an indirect relationship with defaulting borrowers, either via their underwriter or through the CLO participation in the loan syndicate ( $\operatorname{Rel}_{\mathrm{tij}, \mathrm{h}}^{\mathrm{P}}=1$ or $\operatorname{Rel}_{\mathrm{tji}, \mathrm{h}}^{\mathrm{U}}=1$ ), we observe only about a small percent decline in distressed loans before default. However, when CLO managers are affiliated with the arranger of the defaulting loan $\left(\operatorname{Rel}_{\mathrm{tij}, \mathrm{h}}^{\mathrm{M}}=1\right)$, they gradually lower their investment ratio in the distressed loan starting about one year before default. By the time of default, these managers have reduced their exposure by 14 percent.

Although the difference in trading for the CLOs affiliated with loan arrangers is quite distinct, it is not drastic, and on average managers do not totally dispose of the defaulted loan. Arguably, one could expect these better-informed CLO managers to judiciously divest these problem assets. However, we find that the median position held for these CLOs declines from \$3.27 million 12 months before default to $\$ 2$ million at the time of default, and they completely selloff the fifth percentile of their distressed positions. Further, we find that the divestment of “problem” positions is sensitive to their size, with CLO managers more eager to sell larger holdings.

There are many factors that would affect a manager’s propensity to trade. As noted, CLOs are fairly diversified, allowing for some leeway in how managers dispose of problem loans. In contrast to equity securities, which suffer severe losses in the event of default, the resolution of distressed syndicated loans is more dynamic and complex, often involving renegotiations and restructurings that do not always warrant a prompt selloff. For example, as we can see from 
Figure 1, the secondary price of distressed loans does not collapse; it declines from about 86 one year before default to 62 at the day of default.

The differences between CLO managers affiliated with loan arrangers and the remaining CLO managers depicted in Figure 3 appear to be large. However, it is unclear from that figure whether these differences are statistically significant. To that end, we present in Table 4 the regression results determining the effect of CLOs' affiliations on the investment ratio for a 12month horizon before and after default $(\mathrm{H}=12)$. The first column estimates the regression model for an unbalanced panel that includes loan positions with a minimum history of 6 months before the default date. The remaining four panels focus on a fully balanced sample with a complete 12-month history. In general, we observe that the regression findings are very similar for the balanced and unbalanced panels. For this reason, our discussion focuses on the balanced panel results presented in column 3.

The bottom part of the table formally investigates the statistical significance of the privateinformation Hypotheses $1 \mathrm{~A}$ and $1 \mathrm{~B}$ outlined in the previous section. It presents the relevant change for the specified hypothesis and indicates the statistical significance of the underlying Ftest. The first test considers whether different types of relationships influence CLO managers’ trading activity before default (Hypothesis 1A). The maintained hypothesis is that CLO managers would not respond to private news before default, that is $\mathrm{H}_{0}: \bar{\delta}_{\mathrm{B}}^{\mathrm{i}}=0 .{ }^{14}$ As suggested by the graphical analysis (Figure 3), the change in the pre-default investment ratio for CLO managers that have a relationship with borrowers only via their underwriter or syndicate participation ( $\operatorname{Rel}_{\mathrm{tij}, \mathrm{h}}^{\mathrm{P}}$ or $\left.\operatorname{Rel}_{\mathrm{tji}, \mathrm{h}}^{\mathrm{U}}\right)$ and for those with no relationships $\left(\mathrm{NORel}_{\mathrm{tij}}\right)$ are not

\footnotetext{
${ }^{14}$ Although we formally described the hypothesis using a one-sided framework, in practice the statistical tests need to consider the two-sided possibility that the investment ratio can increase or decrease during the specified period.

The F-test is therefore designed to reject the null hypothesis that the trading response $\delta_{\mathrm{B}}^{\mathrm{l}}$ is zero in favor of the alternative that it is either positive or negative.
} 
statistically significant $\left(\bar{\delta}_{\mathrm{B}}^{\mathrm{U}}=-1.53, \bar{\delta}_{\mathrm{B}}^{\mathrm{P}}=2.21\right.$ and $\bar{\delta}_{\mathrm{B}}^{\mathrm{N}}=0.71$, respectively). The negative response on $\bar{\delta}_{\mathrm{B}}^{\mathrm{U}}$ suggests that CLO managers may get some unique information through their underwriters, but the impact of these relationships is generally statistically insignificant. In contrast, the average decline in this 12-month period before default for CLO managers affiliated with the arranger of the defaulting loan $\left(\operatorname{Rel}_{\mathrm{tij}, \mathrm{h}}^{\mathrm{M}}\right)$ is $\bar{\delta}_{\mathrm{B}}^{\mathrm{M}}=-14.1$ and statistically significant.

Hypothesis 1B proposes that the sell-off of distressed loans by CLO managers that are affiliated with the loan arranger is greater before default than the sell-off before default by the remaining CLO managers. Indeed, the average difference between the investment ratio for borrowers with CLO manager-loan arranger relationships and those without any relationships is $\bar{\delta}_{\mathrm{B}}^{\mathrm{M}}-\bar{\delta}_{\mathrm{B}}^{\mathrm{N}}=-14.82$ and statistically significant (Column 3 Table 4, bottom panel).

These findings are robust. To mitigate possible adverse selection loan biases between the relationship groups, we restrict our sample to loans that were granted by the arrangers affiliated with CLOs in our sample. As expected, the sample of borrowers in this test is notably smaller, declining from 244 firms to 46 firms, but it does not affect our findings (Column 4, Table 4).

To lessen possible mismatch problems stemming from loan aggregation, we restrict our sample to borrowers that have only one loan. Recall that, to avoid the problems stemming from the absence of loan identifiers in our data, we focus on CLO managers' overall investment at the borrower level. Restricting the sample to borrowers that have only one loan assures us that CLOs are investing in the same loan. Again, the regression results for this test are similar to our original findings, albeit somewhat weaker in statistical significance (Column 5, Table 4).

The evidence unveiled thus far on the strong statistical decline in the investment ratio in the period leading up to default is consistent with Hypothesis 1 that CLO managers affiliated with the arranger of the defaulting loan use their private information to lower their exposure to 
distressed borrowers before default. There are, however, other potential explanations for our findings. For example, as we can see from Table 4, and in line with the evidence depicted in Figure 3, CLO managers affiliated with the loan arranger appear to continue to divest their investments in distressed loans after they default. While this sell off may also be information driven, given that prices in the secondary loan market stabilize after default (Figure 1), this suggests these CLO managers may have a different risk appetite. Before we look closely at some alternative explanations to our findings, in the next subsection we briefly discuss some additional factors that appear to influence CLO trading.

\subsection{Influence of Other Factors on CLO Trading}

We briefly discuss here the impact of the remaining explanatory variables that we consider in our investigation of CLOs' trading around loan defaults (Table 4, top panel). The large and statistically significant impact of $\log ($ POSITION) signifies that a 10 percent increase (decrease) in borrower holdings would increase (decrease) the investment ratio by about 9 percent. The coefficient of MATURITY is generally negative, suggesting that collateral managers are more inclined to avoid longer maturity loans. While longer duration assets are generally more attractive to institutional investors, collateral managers' portfolio choices might be constrained by guidelines in the CLO indenture that govern weighted average life thresholds. As expected, credit ratings strongly influence the manager's willingness to keep a loan. This is evidenced by the estimated parameters on the credit rating dummy variables, which change from positive to negative as the loan credit rating deteriorates.

Finally, our results show that CLO managers make larger investments in the loans of borrowers in which they also have an equity investment. The positive and statistically significant coefficient of EQUITY_REL indicates that CLO managers retain on average about a 28 percent 
higher investment ratio on those borrowers that they also have an equity investment. ${ }^{15}$ This investment ratio commitment remains unchanged before and after default. This result highlights that CLO managers like private equity firms, which are more likely to intrinsically purchase their subsidiary loans, exhibit no desire to dispose of these distressed assets.

\section{BANK AFFILIATION AND ACCESS TO INFORMATION}

The results unveiled in the previous section suggest that CLOs affiliated with loan arrangers gain access to private information on borrowers. Our regression findings reveal that CLO managers affiliated with loan arrangers lower their exposure to distressed positions before default in comparison to non-relationship managers. In this section we investigate if the trading behavior of those managers is influenced by other factors.

Our sample of CLO managers affiliated with loan arrangers is dominated by banks, which is to be expected because banks are the dominant arrangers in the syndicated loan market. Given that banks are subject to prudential regulation and supervision, and are by extension less prone to take on risk, it is possible that their risk conservatism extends to their CLO affiliates For example, Chernenko (2017) finds that CDO managers with higher franchise by virtue of their affiliation with other businesses were less willing to invest in riskier assets. Other studies also highlight the importance of conflicts of interest that amplify reputational and operational risks. Gopalan, Nanda, and Yerramilli (2011) show that loan arrangers experiencing greater bankruptcies suffer lower rates of participation by investors and attract fewer syndicated loan borrower clients. Perry and de Fontnouvelle (2005) find a significant negative market reaction to the announcement of internal fraud losses for firms with strong shareholder rights.

\footnotetext{
${ }^{15}$ The equity relationship variable is a binary indicator of firm ownership constructed from Capital IQ company information. The equity ownership measure reflects primarily situations where the manager is a private equity owner or a current stakeholder in the firm but excludes 13F share ownerships of listed companies reported to the SEC.
} 
To ascertain the importance of bank-specific factors on loan-arranger affiliated CLOs' trading ahead of default, we begin by comparing the reaction of bank- and nonbank-affiliated CLOs around default without controlling for the presence of loan relationships using the following model:

$$
\mathrm{R}_{\mathrm{tij}}=\alpha_{\mathrm{i}}+\alpha_{\mathrm{t}}+\beta_{1} \mathrm{x}_{\mathrm{tij} \bullet}^{\mathrm{B}}+\beta_{2} \mathrm{x}_{\mathrm{ti} \bullet}^{\mathrm{CLO}}+\sum_{\mathrm{h}=-\mathrm{H}}^{\mathrm{H}} \delta_{\mathrm{h}}^{\mathrm{BANK}} \operatorname{Rel}_{\mathrm{tij}, \mathrm{h}}^{\mathrm{BANK}}+\sum_{\mathrm{h}=-\mathrm{H}}^{\mathrm{H}} \delta_{\mathrm{h}}^{\mathrm{NONBANK}} \operatorname{Rel}_{\mathrm{tij}, \mathrm{h}}^{\text {NONBANK }}+\varepsilon_{\mathrm{tij}} \cdot
$$

If CLO managers affiliated with banks behave more prudently to avoid adversely impacting their affiliated parent franchise value, then they may proactively divest distressed loans before default. If that is the case then we should have $\mathrm{H}_{0}: \bar{\delta}_{\mathrm{B}}^{\mathrm{BANK}} \leq \bar{\delta}_{\mathrm{B}}^{\mathrm{NONBANK}}$.

The estimates of equation (2) reveal a significant difference in the response between and bank- and nonbank-affiliated CLO managers (Table 5, column 1). Bank-affiliated CLO managers decrease their average pre-default exposure by $\bar{\delta}_{\mathrm{B}}^{\text {BANK }}=-10.81$. In contrast, nonbankaffiliated CLO managers slightly increase their pre-default investment ratio in distressed borrowers.

These results are suggestive of a bank-factor. However, since they are based on the entire sample of borrowers, and thus include borrowers that have relationships with the CLO manager, they may stem from differences in the information available to the CLO manager. To address this problem, we restrict our sample to the subset of borrowers that do not have loan relationships with the CLO manager or its underwriter. For these borrowers, bank- and nonbankaffiliated CLOs rely on information provided to all syndicate participants by an unaffiliated loan arranger and other public sources. The findings based on this non-relationship subsample confirm that there is an incremental response from bank-affiliated CLOs to default that is not 
observed by nonbank-affiliated CLOs (Table 5, column 2), adding support to the thesis that bank affiliates have lower risk appetite.

To disentangle the relative importance of private information and bank-specific factors influencing CLO managers’ trading around loan defaults, we estimate a hybrid of the regression specifications (1) and (2):

$$
\begin{aligned}
\mathrm{R}_{\mathrm{tij}}= & \alpha_{\mathrm{i}}+\alpha_{\mathrm{t}}+\beta_{1} \mathrm{x}_{\mathrm{tij} \bullet}^{\mathrm{B}}+\beta_{2} \mathrm{x}_{\mathrm{tj} \bullet}^{\mathrm{CLO}}+\sum_{\mathrm{h}=-\mathrm{H}}^{\mathrm{H}} \delta_{\mathrm{h}}^{\mathrm{M}} \operatorname{Rel}_{\mathrm{tij}, \mathrm{h}}^{\mathrm{M}}+\sum_{\mathrm{h}=-\mathrm{H}}^{\mathrm{H}} \delta_{\mathrm{h}}^{\mathrm{P}} \operatorname{Rel}_{\mathrm{tij}, \mathrm{h}}^{\mathrm{P}}+\sum_{\mathrm{h}=-\mathrm{H}}^{\mathrm{H}} \delta_{\mathrm{h}}^{\mathrm{U}} \operatorname{Rel}_{\mathrm{tijh}}^{\mathrm{U}}+\sum_{\mathrm{h}=-\mathrm{H}}^{\mathrm{H}} \delta_{\mathrm{h}}^{\mathrm{N}-\mathrm{BANK}} \operatorname{NORel}_{\mathrm{tij}, \mathrm{h}}^{\mathrm{BANK}} \\
& +\sum_{\mathrm{h}=-\mathrm{H}}^{\mathrm{H}} \delta_{\mathrm{h}}^{\mathrm{N}-\mathrm{NONBANK}} \operatorname{NORel}_{\mathrm{tij}, \mathrm{h}}^{\mathrm{NONANK}}+\varepsilon_{\mathrm{tij}} \cdot
\end{aligned}
$$

This specification decomposes the dummy explanatory variable $\mathrm{NORel}_{\mathrm{tij}}$ (for CLO managers

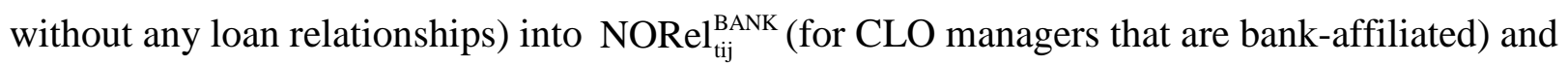
NORel $_{\text {tij }}^{\text {NONBANK }}$ (for nonbank-affiliated CLO managers). This decomposition is particularly useful because there is a large overlap between CLO managers affiliated with arrangers of defaulting loans $\left(\operatorname{Rel}_{\mathrm{tij}}^{\mathrm{M}}=1\right)$ and CLO managers affiliated with banks that invest in non-relationship loans $\left(\mathrm{NORel}_{\mathrm{tij}}^{\text {BANK }}=1\right)$. Specifically, 37 bank-affiliated CLOs in our sample are managed by 21 unique banks (Table 1). Moreover, bank managers that are arrangers (represented by $\operatorname{Rel}_{\mathrm{tij}}^{\mathrm{M}}=1$ ) hold about 70 percent of the loans without any relationships (indicated by $\mathrm{NORel}_{\mathrm{tij}}^{\mathrm{BANK}}=1$ ).

That overlap provides a useful comparison for testing the importance of private information because the trading decisions on loans with and without relationships are made largely by the same core group of bank-affiliated CLO managers. Essentially, the regression parameter $\delta_{\mathrm{B}}^{\mathrm{M}}$ in model (3) represents how bank-affiliated CLO managers trade their “own” arranged loans, while $\delta_{\mathrm{B}}^{\mathrm{N}-\mathrm{BANK}}$ indicates how this same set of CLO managers trade non-affiliated loans. If loan relationships do not offer any informational advantages before default, then bank-affiliated CLO 
managers should trade relationship defaulting loans and non-relationship defaulting loans in a similar fashion; more precisely, we should find $\mathrm{H}_{0}: \bar{\delta}_{\mathrm{B}}^{\mathrm{N}-\mathrm{BANK}}=\bar{\delta}_{\mathrm{B}}^{\mathrm{M}}$. If, on the other hand, CLO managers trade their own relationship loans more aggressively in the period leading up to default, that will provide support to the idea that they rely on private information. Our results support the latter hypothesis (Table 6, bottom half): we find a decline of 24.48 percent in positions for CLOs with loan relationships and only a 4.04 percent decline in positions held by CLOs having no explicit relationship with the borrower.

It is possible that loan arrangers, and by association their affiliated CLO managers, are more averse to holding their arranged problem loans. Absent this possibility, the latest findings showing that bank-affiliated CLO managers are more aggressive at divesting loans arranged by their bank that fall into distress (when compared to loans that also fall into distress but which were not arranged by their bank) provide important support to the thesis that CLO managers affiliated with loan arrangers gain access to unique information on borrowers.

The latest results are important for yet another reason: they alleviate those concerns that our findings are driven by CLO managers' loan re-pricing policies. CLO collateral normally values securities at par to avoid the unnecessary problems that come with mark-to-market volatility. However, CLO managers are expected to re-price their collateral at the fair market value or recovery value in the event of default. Arguably, the apparent drop in investment ratio in the months leading up to default could stem from loan re-pricing rather than loan sales. This drop, however, would require CLO managers to follow different practices depending on whether the loan was arranged by their affiliated bank or by another institution, which is unlikely.

Further, in addition to providing information of CLO positions, the Moody's database that we use also includes a separate module tracing CLOs’ trading transactions. One drawback with 
the transactions data is that it is mostly compiled from independent trustee reports without common loan identifiers to link with the positions' information. Nevertheless, using the available loan identifier or loan facility names, we were able to merge a significant segment of the CLO positions and transactions data. Overall, this exercise reveals that most of the nontrivial changes in loan positions are associated with specific trading transactions. It is also interesting to note that managers sometimes report the primary reason for the transaction. About 82 percent of the trading activity is discretionary and is related to the credit deterioration or improvement of the loan asset. The remaining trading activity is nondiscretionary, triggered mostly by corporate restructuring, debt refinancing, redemptions, and loan exchanges.

\section{CONCLUSION}

The originate-to-distribute model of securitization is an important innovation in financial intermediation. This paper focuses on CLOs, which enable lenders to originate and distribute loans to investors. We use a unique database of CLO trading transactions to investigate the impact of the institutional affiliations of CLO managers on their trading activity. Our analysis focuses on the trading behavior of CLO managers affiliated with loan arrangers, a connection that may give them access to private information held by the loan arranger.

Our regression analysis, examining CLO managers’ trading of loans to borrowers that default, reveals that CLO managers affiliated with the arranger of these loans (mostly banks) sell large portions of their positions before default. In contrast, CLO managers that do not have a similar affiliation do not divest their exposures.

This finding is consistent with the thesis that bank-affiliated CLO managers are more risk conservative, possibly to protect the franchise value of their parent institutions, as well as the thesis that bank-affiliated CLO managers gain access to private information by virtue of their 
parent role in the syndicated loan market. While we cannot rule out either one of these explanations, we unveil evidence in support of the information thesis.

Our paper suggests some fruitful topics for future research. For example, given that prices in the secondary loan market decline significantly in the months leading up to default, there is likely value in a preemptive sell off strategy. However, it is unclear from our investigation whether this strategy has a positive effect on CLOs' performance. As additional data on CLOs becomes available, it would be interesting to investigate the impact of CLO manager's affiliation on performance.

Our sample overlaps significantly with the 2008 financial crisis, which was characterized by a significant rise in corporate defaults. This period provides a useful laboratory for examining the trading behavior of CLO managers around default, but the crisis may have had a unique impact on their trading strategies. Therefore, another fruitful topic for future research is to investigate the impact of CLO managers' relationships with loan arrangers on their trading activity during normal times. Yet another potentially interesting area for future research is to investigate whether the selloffs by bank-affiliated CLO managers that we identified constraint parent banks’ ability to originate loans and “distribute” them through their affiliated CLOs. 


\section{REFERENCES}

Benmelech, E., J. Dlugosz, and V. Ivashina. (2012) “Securitization without Adverse Selection: The Case of CLOs.” Journal of Financial Economics 106, 91-113.

Bord, V. and J. Santos (2012). "The Rise of the Originate-to-Distribute Model and the Role of Banks in Financial Intermediation.” Federal Reserve Bank of New York Economic Policy Review 18, 21-34.

Bord, V. and J. Santos (2015). "Does Securitization of Corporate Loans Lead to Riskier Lending?”Journal of Money, Credit and Banking 47, 415-444.

Brown, J. (2007). "Understanding Reputational Risk: Identify, Measure, and Mitigate the Risk,” SRC Insights, 12(2), 11-14. https://www.philadelphiafed.org/bank-resources/publications/srcinsights/2007/fourth-quarter/q4si1_07

Bushman, R., A. Smith, and R. Wittenberg-Moerman (2011). "Price Discovery and Dissemination of Private Information by Loan Syndicate Participants," Journal of Accounting Research (2011), 921-972.

Cameron, C. and D. Miller. "A Practitioner's Guide to Cluster-Robust Inference", Journal of Human Resources 50 (2015), 317-373.

Cetorelli, N., and S. Peristiani (2012). "The Role of Banks in Asset Securitization,” Federal Reserve Bank of New York Economic Policy Review 18, 47-63.

Chernenko, S. (2017). "The Front Men of Wall Street: The Role of CDO Collateral Managers in the CDO Boom and Bust," Journal of Finance 72, 1893-1936.

Gopalan, R., Nanda, V., \& Yerramilli, V. (2011). "Does poor performance damage the reputation of financial intermediaries? Evidence from the loan syndication market” Journal of Finance 66, 2083-2120.

Guo, Z., and S. Zhang (2015). "The Syndicate Structure of Securitized Corporate Loans,” Working Paper. http://swfa2015.uno.edu/E_Debt_Management/SWFA2015_Paper_146.pdf

Ivashina, V. and Z. Sun (2011). “Institutional stock trading on loan market information” Journal of Financial Economics 100(2), 284-303.

Lou, Y., M. Loumioti, and F. Vasvari (2014). “CLOs’ Trading Activity and Performance,” Working Paper, 2014.

https://www.kellogg.northwestern.edu/departments/accounting/ /media/A41AC10049B4473 293086BDA5231775C.ashx

Loumioti, M., and F. Vasvari (2016). "Portfolio Performance Manipulation in Collateralized Loan Obligations,” Working Paper.

http://papers.ssrn.com/sol3/papers.cfm?abstract_id=2803704

Massoud, N., D. Nandy, A. Saunders, and K. Song (2009). "Do Hedge Funds Trade on Private Information? Evidence from Syndicated Lending and Short-Selling," Journal of Financial Economics 99, 477-499. 
Nadauld, T., and M. Weisbach (2014). "Did Securitization Affect the Cost of Corporate Debt?” Journal of Financial Economics 105, 332-352.

Paligorova, T., and J. Santos (2016). “Non-Bank Investors and Loan Renegotiations,” Federal Reserve Bank of New York, Working Paper.

Perry, J., and P. de Fontnouvelle (2005). "Measuring Reputational Risk: The Market Reaction to Operational Loss Announcements” Working Paper. https://www.bostonfed.org/-/media/Documents/ar/PDF/jppd1005.pdf?la=en

Peristiani, S., and J. Santos (2015). "Investigating the Trading Activities of CLO Portfolio Managers,” Liberty Street Economics, August 3, 2015. http://libertystreeteconomics.newyorkfed.org/2015/08/investigating-the-trading-activity-ofclo-portfolio-managers.html\#.

Petersen, M. (2004) .“Information: Hard and Soft,” Kellogg School of Management Northwestern University, Working Paper. http://www.kellogg.northwestern.edu/faculty/petersen/htm/papers/softhard.pdf

Shivdasani, A., and Y. Wang. “Did Structured Credit Fuel the LBO Boom?” Journal Finance 66 (2011), 1291-1328 
Table 1. Collateral manager distribution of the CLO sample, 2007-2011

\begin{tabular}{|c|c|c|c|c|c|}
\hline & $\begin{array}{c}\text { Number of } \\
\text { CLOs }\end{array}$ & $\begin{array}{l}\% \text { of } \\
\text { CLOs }\end{array}$ & $\begin{array}{c}\text { Median CLO } \\
\text { Balance } \\
\text { (\$ Millions) }\end{array}$ & $\begin{array}{l}\text { Number of } \\
\text { Institutions }\end{array}$ & Default Rate \\
\hline \multicolumn{6}{|l|}{ Collateral Manager Type } \\
\hline Banks & 55 & 23.01 & 500 & 22 & 0.19 \\
\hline Hedge Funds & 31 & 12.97 & 487 & 18 & 0.26 \\
\hline Insurance Firms & 19 & 7.95 & 423 & 5 & 0.29 \\
\hline Investment Firms & 98 & 41.00 & 494 & 43 & 0.22 \\
\hline PE Firms & $\underline{36}$ & 15.06 & 484 & $\underline{12}$ & 0.28 \\
\hline & 239 & & & 100 & \\
\hline \multicolumn{6}{|l|}{ CLO Underwriter Type } \\
\hline Banks & 239 & & & & \\
\hline Number of Borrowers & 5,039 & & & & \\
\hline Panel Size & $1,471,565$ & & & & \\
\hline Borrowers $\times$ CLOs & 65,129 & & & & \\
\hline
\end{tabular}

Notes: The table presents basic summary statistics for the entire cross-sectional time series sample of CLOs. Default rate $=$ the fraction of borrowers that experienced default during the sample period. Number of institutions = unique number of firms that manage the CLOs. Number of borrowers $=$ firms with loans held in all CLO portfolios. 
Table 2. Summary Statistics for Panel Sample of Defaulted Borrowers, 2007-2011

\begin{tabular}{|c|c|c|c|c|}
\hline $\begin{array}{l}\text { REGRESSION VARIABLES } \\
\text { (Panel index dimensions: month (t), CLO (j), borrower (i)) }\end{array}$ & Mean & Median & $1^{\text {st }}$ Pctl & $99^{\text {th }}$ Pctl \\
\hline \multicolumn{5}{|l|}{ DEPENDENT VARIABLE } \\
\hline $\begin{array}{l}\text { Investment Ratio } \mathrm{R}_{\mathrm{tij}}=\text { Aggregate position held at month ( } \mathrm{t} \text { ) } \\
\text { divided by the initial position ( } \mathrm{t}=0 \text { ) (percent) }\end{array}$ & 136.9 & 99.24 & 0.21 & 10,000 \\
\hline \multicolumn{5}{|l|}{ EXPLANATORY VARIABLES } \\
\hline \multicolumn{5}{|l|}{ Borrower/Loan Characteristics $\mathrm{x}_{\text {tij॰ }}^{\mathrm{B}}$} \\
\hline POSITION = Nominal position held ( $\$$ millions) & 3.81 & 2.41 & 0.002 & 25.75 \\
\hline US_FIRM = 1 if borrower is US domiciled & 0.95 & & & \\
\hline \%ISSUE_OWNED = Percent of entire issue owned by CLO & 4.25 & 0.25 & 0.0022 & 37.9 \\
\hline MATURITY = Weighted remaining loan maturity (years) & 4.25 & 4.00 & 0.050 & 7.00 \\
\hline $\begin{array}{l}\text { EQUITY_REL = } 1 \text { if manager has equity relationships with } \\
\text { borrower }\end{array}$ & 0.04 & & & \\
\hline \multicolumn{5}{|l|}{ Rating Indicators } \\
\hline AAA to BBB- & 0.0003 & & & \\
\hline $\mathrm{BB}+$ & 0.0024 & & & \\
\hline BB & 0.0151 & & & \\
\hline BB- & 0.0163 & & & \\
\hline $\mathrm{B}^{+}$ & 0.0580 & & & \\
\hline B & 0.2029 & & & \\
\hline B- & 0.2177 & & & \\
\hline CCC+ & 0.2484 & & & \\
\hline CCC & 0.1108 & & & \\
\hline CCC- & 0.0718 & & & \\
\hline $\mathrm{CC}+$ to $\mathrm{C}$ & 0.0563 & & & \\
\hline \multicolumn{5}{|l|}{ Manager-Borrower Loan Relationships } \\
\hline No Relationship, NORel $_{\mathrm{tji}}$ & 0.67 & & & \\
\hline Manager is loan arranger, $\mathrm{Rel}_{\mathrm{tii}}^{\mathrm{M}}$ & 0.03 & & & \\
\hline Underwriter is loan arranger $\operatorname{Rel}_{\text {tii }}^{\mathrm{U}}$ & 0.19 & & & \\
\hline Underwriter or manager are loan participants $\operatorname{Rel}_{t \mathrm{ti}}^{\mathrm{P}}$ & 0.11 & & & \\
\hline \multicolumn{5}{|l|}{ CLO Characteristics $\mathrm{x}_{\mathrm{tj} \cdot}^{\mathrm{CLO}}$} \\
\hline CLO_BALANCE = CLO balance ( $\$$ millions) & 573 & 487 & 258.5 & 2,018 \\
\hline Number of Defaulted Borrowers in Panel & 376 & & & \\
\hline Number of Observations in Panel & 148,486 & & & \\
\hline
\end{tabular}

Notes: This table summarizes the explanatory and dependent variables of the regression sample. All continuous explanatory variables are winsorized at the 1- and 99-percentile level. The actual size of the various regression samples is smaller because of the pertinent subsets of borrowers. The overall sample size indicates the maximum number observations available for most regression variables. 
Table 3. Cross-tabulation of CLO manager relationship role by institution type for sample of defaulted borrowers

\begin{tabular}{|c|c|c|c|c|c|c|c|}
\hline & & Banks & $\begin{array}{l}\text { Hedge } \\
\text { Funds }\end{array}$ & $\begin{array}{l}\text { Insurance } \\
\text { Firms }\end{array}$ & $\begin{array}{c}\text { Asset } \\
\text { Managers }\end{array}$ & $\begin{array}{c}\text { PE } \\
\text { Firms }\end{array}$ & $\begin{array}{c}\text { Total } \\
\text { \%Column }\end{array}$ \\
\hline \multirow{3}{*}{ Manager is arranger } & Number & 201 & 3 & 0 & 9 & 2 & 215 \\
\hline & \%Row & 93.49 & 1.4 & 0 & 4.19 & 0.93 & \\
\hline & \%Column & 9.28 & 0.19 & 0 & 0.18 & 0.12 & 1.93 \\
\hline \multirow{3}{*}{$\begin{array}{l}\text { Manager is participant } \\
\text { or underwriter is } \\
\text { participant }\end{array}$} & Number & 265 & 169 & 98 & 588 & 133 & 1,253 \\
\hline & \%Row & 21.15 & 13.49 & 7.82 & 46.93 & 10.61 & \\
\hline & \%Column & 12.23 & 10.56 & 12.25 & 12 & 8.12 & 18.08 \\
\hline \multirow{3}{*}{ Underwriter is arranger } & Number & 395 & 346 & 124 & 896 & 247 & 2,008 \\
\hline & \%Row & 19.67 & 17.23 & 6.18 & 44.62 & 12.3 & \\
\hline & \%Column & 18.24 & 21.63 & 15.5 & 18.29 & 15.08 & 11.28 \\
\hline \multirow{3}{*}{ No relationship } & Number & 1305 & 1082 & 578 & 3,407 & 1,256 & 7,628 \\
\hline & \%Row & 17.11 & 14.18 & 7.58 & 44.66 & 16.47 & \\
\hline & \%Column & 60.25 & 67.63 & 72.25 & 69.53 & 76.68 & 68.71 \\
\hline \multirow{2}{*}{ Total } & Total & 2,166 & 1,600 & 800 & 4,900 & 1,638 & 11,104 \\
\hline & \%Row & 19.51 & 14.41 & 7.2 & 44.13 & 14.75 & 100 \\
\hline
\end{tabular}

Notes. The table cross-tabulates the frequency of defaulted borrower relationships by institutional type of CLO manager. 
Table 4. Influence of loan relationships on investment ratio 12-months before and after default (balanced panel borrowers)

$$
\mathrm{R}_{\mathrm{tij}}=\alpha_{\mathrm{t}}+\alpha_{\mathrm{i}}+\beta_{1} \mathrm{x}_{\mathrm{tij} \bullet}^{\mathrm{B}}+\beta_{2} \mathrm{x}_{\mathrm{tij} \bullet}^{\mathrm{CLO}}+\sum_{\mathrm{h}=-12}^{12} \delta_{\mathrm{h}}^{\mathrm{M}} \operatorname{Re}_{\mathrm{tijh}}^{\mathrm{M}}+\sum_{\mathrm{h}=-12}^{12} \delta_{\mathrm{h}}^{\mathrm{P}} \operatorname{Rel}_{\mathrm{tij}, \mathrm{h}}^{\mathrm{P}}+\sum_{\mathrm{h}=-12}^{12} \delta_{\mathrm{h}}^{\mathrm{U}} \operatorname{Rel}_{\mathrm{tij}, \mathrm{h}}^{\mathrm{U}}+\sum_{\mathrm{h}=-12}^{12} \delta_{\mathrm{h}}^{\mathrm{N}} \mathrm{NORel}_{\mathrm{tij}, \mathrm{h}}+\varepsilon_{\mathrm{tij}} \cdot
$$

Dependent variable: Borrower investment ratio $\mathrm{R}_{\mathrm{tij}}$ (percent)

\begin{tabular}{|c|c|c|c|c|c|}
\hline & \multirow{2}{*}{$\begin{array}{c}\text { Unbalanced } \\
\text { Sample } \\
\text { All } \\
\text { Borrowers } \\
\text { [1] }\end{array}$} & \multicolumn{4}{|c|}{ Balanced Sample 12 Months Around Default } \\
\hline & & $\begin{array}{c}\text { All } \\
\text { Borrowers } \\
{[2]}\end{array}$ & $\begin{array}{c}\text { All } \\
\text { Borrowers } \\
{[3]}\end{array}$ & $\begin{array}{c}\text { Manager- } \\
\text { Arranger } \\
\text { Borrowers } \\
{[4]}\end{array}$ & $\begin{array}{c}\text { Single } \\
\text { Security } \\
\text { Loans } \\
{[5]}\end{array}$ \\
\hline Log(POSITION) & $\begin{array}{c}69.27 * * * \\
(117.90)\end{array}$ & $\begin{array}{c}73.11^{* * *} \\
(101.66)\end{array}$ & $\begin{array}{c}93.27^{* * *} \\
(116.64)\end{array}$ & $\begin{array}{c}112.25^{* * *} \\
(78.50)\end{array}$ & $\begin{array}{c}81.57 * * * \\
(82.70)\end{array}$ \\
\hline \%ISSUE_OWNED & $\begin{array}{c}-2.32 * * * \\
(-25.55)\end{array}$ & $\begin{array}{l}-2.64 * * * \\
(-27.30)\end{array}$ & $\begin{array}{c}-1.80 * * * \\
(-14.01)\end{array}$ & $\begin{array}{c}-2.06 * * * \\
(-6.19)\end{array}$ & $\begin{array}{c}-1.51 * * * \\
(-9.40)\end{array}$ \\
\hline MATURITY & $\begin{array}{c}-2.22 * * * \\
(-6.49)\end{array}$ & $\begin{array}{c}-1.53 * * * \\
(-4.98)\end{array}$ & $\begin{array}{c}0.08 \\
(0.18)\end{array}$ & $\begin{array}{c}-14.15^{* * *} \\
(-10.64)\end{array}$ & $\begin{array}{c}0.22 \\
(0.37)\end{array}$ \\
\hline US_FIRM & $\begin{array}{l}-4.72 * \\
(-1.87)\end{array}$ & $\begin{array}{c}-9.27 * * * \\
(-2.89)\end{array}$ & $\begin{array}{l}-8.36 * * \\
(-2.43)\end{array}$ & $\begin{array}{c}-9.29 \\
(-1.19)\end{array}$ & $\begin{array}{c}-15.13 * * * \\
(-2.62)\end{array}$ \\
\hline EQUITY_REL & $\begin{array}{c}14.64^{* * *} \\
(9.55)\end{array}$ & $\begin{array}{c}17.16^{* * *} \\
(8.59)\end{array}$ & $\begin{array}{c}28.75^{* * *} \\
(12.78)\end{array}$ & $\begin{array}{c}22.53 * * * \\
(6.10)\end{array}$ & $\begin{array}{c}29.02 * * * \\
(10.72)\end{array}$ \\
\hline CLO_BALANCE & $\begin{array}{c}-0.03 * * * \\
(-36.80)\end{array}$ & $\begin{array}{c}-0.03 * * * \\
(-25.31)\end{array}$ & & & \\
\hline AAA to BBB- & $\begin{array}{c}20.09 * * * \\
(3.13)\end{array}$ & $\begin{array}{c}-2.59 \\
(-0.65)\end{array}$ & $\begin{array}{c}0.95 \\
(0.32)\end{array}$ & $\begin{array}{c}8.77 \\
(0.86)\end{array}$ & $\begin{array}{c}-6.83 \\
(-0.61)\end{array}$ \\
\hline $\mathrm{BB}+$ & $\begin{array}{c}4.06 \\
(0.91)\end{array}$ & $\begin{array}{c}20.78 * * * \\
(3.64)\end{array}$ & $\begin{array}{c}31.53^{* * *} \\
(5.61)\end{array}$ & $\begin{array}{c}64.72 * * * \\
(6.28)\end{array}$ & $\begin{array}{c}-20.89 * * * \\
(-2.93)\end{array}$ \\
\hline $\mathrm{BB}$ & $\begin{array}{c}-8.48 * * * \\
(-2.61)\end{array}$ & $\begin{array}{l}-7.43^{*} \\
(-1.82)\end{array}$ & $\begin{array}{c}0.45 \\
(0.11)\end{array}$ & $\begin{array}{c}-10.36^{*} \\
(-1.73)\end{array}$ & $\begin{array}{c}3.94 \\
(0.77)\end{array}$ \\
\hline BB- & $\begin{array}{c}19.61^{* * *} \\
(10.22)\end{array}$ & $\begin{array}{c}13.43^{* * *} \\
(6.27)\end{array}$ & $\begin{array}{c}20.35^{* * *} \\
(9.35)\end{array}$ & $\begin{array}{c}27.59 * * * \\
(7.58)\end{array}$ & $\begin{array}{c}15.73 * * * \\
(6.23)\end{array}$ \\
\hline $\mathrm{B}+$ & $\begin{array}{c}1.40 \\
(1.07)\end{array}$ & $\begin{array}{c}2.47 \\
(1.60)\end{array}$ & $\begin{array}{c}8.67 * * * \\
(5.48)\end{array}$ & $\begin{array}{c}6.31^{* *} \\
(2.17)\end{array}$ & $\begin{array}{c}7.65 * * * \\
(4.07)\end{array}$ \\
\hline B & $\begin{array}{c}1.72 \\
(1.54)\end{array}$ & $\begin{array}{l}2.43^{*} \\
(1.88)\end{array}$ & $\begin{array}{c}5.59 * * * \\
(4.16)\end{array}$ & $\begin{array}{l}4.81^{*} \\
(1.79)\end{array}$ & $\begin{array}{c}3.76 * * \\
(2.47)\end{array}$ \\
\hline B- & $\begin{array}{c}-1.23 \\
(-1.20)\end{array}$ & $\begin{array}{c}-0.08 \\
(-0.06)\end{array}$ & $\begin{array}{c}2.67 * * \\
(2.10)\end{array}$ & $\begin{array}{c}0.96 \\
(0.36)\end{array}$ & $\begin{array}{c}-0.40 \\
(-0.27)\end{array}$ \\
\hline $\mathrm{CCC}+$ & $\begin{array}{c}0.40 \\
(0.33)\end{array}$ & $\begin{array}{c}0.84 \\
(0.60)\end{array}$ & $\begin{array}{c}5.80 * * * \\
(4.02)\end{array}$ & $\begin{array}{c}1.26 \\
(0.39)\end{array}$ & $\begin{array}{l}3.05^{*} \\
(1.92)\end{array}$ \\
\hline CCC & $\begin{array}{c}-1.61 \\
(-1.20)\end{array}$ & $\begin{array}{c}-0.38 \\
(-0.25)\end{array}$ & $\begin{array}{l}2.87^{*} \\
(1.77)\end{array}$ & $\begin{array}{c}3.81 \\
(1.07)\end{array}$ & $\begin{array}{c}3.80 * * \\
(2.19)\end{array}$ \\
\hline CCC- & $\begin{array}{c}-9.87 * * * \\
(-6.22)\end{array}$ & $\begin{array}{c}-1.96 \\
(-1.16)\end{array}$ & $\begin{array}{c}0.13 \\
(0.07)\end{array}$ & $\begin{array}{c}0.86 \\
(0.18)\end{array}$ & $\begin{array}{c}0.31 \\
(0.15)\end{array}$ \\
\hline CC to $\mathrm{C}$ & $\begin{array}{c}-13.76^{* * *} \\
(-5.55)\end{array}$ & $\begin{array}{l}-6.13^{* *} \\
(-2.14)\end{array}$ & $\begin{array}{c}-1.82 \\
(-0.61)\end{array}$ & $\begin{array}{c}-6.98 \\
(-1.15) \\
\end{array}$ & $\begin{array}{c}0.63 \\
(0.18) \\
\end{array}$ \\
\hline
\end{tabular}




\begin{tabular}{|c|c|c|c|c|c|}
\hline $\begin{array}{l}\text { Hypothesis } 1 \mathrm{~A} \text {. Are managers selling } \\
\text { before default? }\end{array}$ & & & $\underline{\bar{\delta}_{\mathrm{B}}^{\mathrm{i}}}$ & & \\
\hline $\begin{array}{l}\text { Manager-arranger relationships } \bar{\delta}_{\mathrm{B}}^{\mathrm{M}} \leq 0 \\
\text { Managers with participant relationships }\end{array}$ & $-11.49 * * *$ & $-25.25 * * *$ & $-14.10 * * *$ & -1.63 & $-16.04 * * *$ \\
\hline $\bar{\delta}_{\mathrm{B}}^{\mathrm{p}} \leq 0$ & 2.84 & $4.96^{* *}$ & 2.21 & $10.03 * * *$ & $10.79 * * *$ \\
\hline Managers with no relationships $\bar{\delta}_{\mathrm{B}}^{\mathrm{N}} \leq 0$ & $2.64 * * *$ & 0.99 & 0.71 & $5.15^{* *}$ & 0.99 \\
\hline $\begin{array}{l}\text { Managers with underwriter relationships } \\
\bar{\delta}_{\mathrm{B}}^{\mathrm{U}} \leq 0 \\
\text { Hypothesis } 1 B . \text { Who is more responsive } \\
\text { before default? }\end{array}$ & 0.95 & 1.14 & $\underline{\bar{\delta}_{\mathrm{B}}^{\imath}-\bar{\delta}_{\mathrm{B}}^{\kappa}}$ & -0.54 & $-4.68 * *$ \\
\hline $\begin{array}{l}\text { Manager-arranger more responsive than } \\
\text { participant } \bar{\delta}_{\mathrm{B}}^{\mathrm{M}}-\bar{\delta}_{\mathrm{B}}^{\mathrm{P}} \leq 0\end{array}$ & $-14.34 * * *$ & $-30.21 * * *$ & $-16.31 * * *$ & $-11.66^{*}$ & $-26.84 * * *$ \\
\hline $\begin{array}{l}\text { Manager-arranger more responsive than } \\
\text { no-relationship manager } \bar{\delta}_{\mathrm{B}}^{\mathrm{M}}-\bar{\delta}_{\mathrm{B}}^{\mathrm{N}} \leq 0\end{array}$ & $-14.13 * * *$ & $-26.24 * * *$ & $-14.82 * * *$ & -6.79 & $-17.03^{* * *}$ \\
\hline $\begin{array}{l}\text { Manager-arranger more responsive than } \\
\text { underwriter manager } \bar{\delta}_{\mathrm{B}}^{\mathrm{M}}-\bar{\delta}_{\mathrm{B}}^{\mathrm{U}} \leq 0\end{array}$ & $-12.44 * * *$ & $-26.39 * * *$ & $-12.57 * * *$ & -1.09 & $-11.37 * *$ \\
\hline Post-Default Response, $\bar{\delta}_{\mathrm{A}}^{\mathrm{M}}$ & $-19.20 * * *$ & $-30.10 * * *$ & $-19.01^{* * *}$ & $-8.88 *$ & $-19.45^{* * *}$ \\
\hline $\begin{array}{l}\text { Borrower Fixed Effects } \\
\text { CLO deal Fixed Effects } \\
\text { Year and Month Time Effects }\end{array}$ & $\begin{array}{l}\text { Yes } \\
\text { No } \\
\text { Yes }\end{array}$ & $\begin{array}{l}\text { Yes } \\
\text { No } \\
\text { Yes }\end{array}$ & $\begin{array}{l}\text { Yes } \\
\text { Yes } \\
\text { Yes }\end{array}$ & $\begin{array}{l}\text { Yes } \\
\text { Yes } \\
\text { Yes }\end{array}$ & $\begin{array}{l}\text { Yes } \\
\text { Yes } \\
\text { Yes }\end{array}$ \\
\hline Number Observations & 141,124 & 92,340 & 92,340 & 46,019 & 49,863 \\
\hline Number of Borrowers & 374 & 0.26 & 244 & 46 & 229 \\
\hline $\mathrm{R}^{2}$ & 0.23 & 0.26 & 0.35 & 0.32 & 0.35 \\
\hline
\end{tabular}

Notes: The table presents the regression estimates of the investment ratio regression model formally defined by equation (1). The first column summarizes the regression estimates for an unbalanced panel that assumes the borrower had a minimum of 6-month history before and after the event of default. The remaining columns present the regression results based on a balanced sample of borrowers that had at least 12-month history before and after default. Column (4) estimates the model for only borrowers that have an extant loan relationship with CLO managers. The last column examines only single loan positions. The hypothesis tests panel presents the average value of the maintained hypothesis with its corresponding F-value significance. The null hypotheses of $\bar{\delta}_{\mathrm{B}}^{\imath} \leq 0$ or $\bar{\delta}_{\mathrm{B}}^{\imath}-\bar{\delta}_{\mathrm{B}}^{\kappa} \leq 0$ are accepted when the values are negative and statistically significant. When the values are positive and statistically significant the null is rejected in favor of the alternative. The regression panel model was estimated using a GLS feasible approach that corrects for borrower clustered error heteroskedasticity (Cameron and Miller 2015). The symbols $(*),(* *)$, and $(* * *)$ indicate statistical significance at the 10-, 5- and 1-percent level. 
Table 5. Importance of regulatory structure: Response of bank and nonbank managers

$$
\mathrm{R}_{\mathrm{tij}}=\alpha_{\mathrm{i}}+\alpha_{\mathrm{t}}+\beta_{1} \mathrm{x}_{\mathrm{tij} \bullet}^{\mathrm{B}}+\beta_{2} \mathrm{x}_{\mathrm{t} \mathrm{c} \bullet}^{\mathrm{CLO}}+\sum_{\mathrm{h}=-12}^{12} \delta_{\mathrm{h}}^{\mathrm{BANK}} \operatorname{Rel}_{\mathrm{tij}, \mathrm{h}}^{\mathrm{BANK}}+\sum_{\mathrm{h}=-12}^{12} \delta_{\mathrm{h}}^{\mathrm{NONBANK}} \operatorname{Rel}_{\mathrm{tij}, \mathrm{h}}^{\mathrm{NONBANK}}+\varepsilon_{\mathrm{tij}} \cdot
$$

Dependent variable: Borrower investment ratio $\mathrm{R}_{\mathrm{tij}}$ (percent)

\begin{tabular}{|c|c|c|c|}
\hline & \multicolumn{3}{|c|}{ Balanced 12-month Panel } \\
\hline & $\begin{array}{c}\text { All } \\
\text { Borrowers } \\
{[1]}\end{array}$ & $\begin{array}{c}\text { Borrowers } \\
\text { Without } \\
\text { Relationships } \\
\text { [2] }\end{array}$ & $\begin{array}{c}\text { Borrowers } \\
\text { With } \\
\text { Relationships } \\
\text { [3] }\end{array}$ \\
\hline Log(POSITION) & $\begin{array}{l}\text { 73.19*** } \\
(102.05)\end{array}$ & $\begin{array}{c}68.90 * * * \\
(89.76)\end{array}$ & $\begin{array}{c}87.05 * * * \\
(64.42)\end{array}$ \\
\hline \%ISSUE_OWNED & $\begin{array}{l}-2.62 * * * \\
(-26.77)\end{array}$ & $\begin{array}{l}-2.22 * * * \\
(-22.38)\end{array}$ & $\begin{array}{c}-2.97 * * * \\
(-10.38)\end{array}$ \\
\hline MATURITY & $\begin{array}{c}-1.51 * * * \\
(-4.93)\end{array}$ & $\begin{array}{c}-0.45 \\
(-1.45)\end{array}$ & $\begin{array}{c}-5.45 * * * \\
(-7.26)\end{array}$ \\
\hline US_FIRM & $\begin{array}{c}-9.01 * * * \\
(-2.83)\end{array}$ & $\begin{array}{c}-7.33 * * \\
(-2.20)\end{array}$ & $\begin{array}{c}-9.67 \\
(-1.38)\end{array}$ \\
\hline EQUITY_REL & $\begin{array}{c}16.52 * * * \\
(8.30)\end{array}$ & $\begin{array}{c}25.80 * * * \\
(11.94)\end{array}$ & $\begin{array}{c}-3.47 \\
(-0.82)\end{array}$ \\
\hline CLO Balance & $\begin{array}{c}-0.03 * * * \\
(-15.6)\end{array}$ & $\begin{array}{c}-0.03 * * * \\
(-15.6)\end{array}$ & $\begin{array}{l}-0.03 * * * \\
(-10.52)\end{array}$ \\
\hline AAA to BBB- & $\begin{array}{c}-3.31 \\
(-0.84)\end{array}$ & $\begin{array}{c}-4.38 \\
(-1.12)\end{array}$ & $\begin{array}{c}-3.47 \\
(-0.82)\end{array}$ \\
\hline $\mathrm{BB}+$ & $\begin{array}{c}19.94^{* * * *} \\
(3.50)\end{array}$ & $\begin{array}{l}11.50 \\
(1.61)\end{array}$ & $\begin{array}{c}-5.17 \\
(-0.16)\end{array}$ \\
\hline $\mathrm{BB}$ & $\begin{array}{l}-7.32 * \\
(-1.79)\end{array}$ & $\begin{array}{c}-1.21 \\
(-0.26)\end{array}$ & $\begin{array}{c}31.30 * * * \\
(3.78)\end{array}$ \\
\hline BB- & $\begin{array}{c}13.73^{* * * *} \\
(6.41)\end{array}$ & $\begin{array}{c}9.15^{* * *} \\
(4.02)\end{array}$ & $\begin{array}{c}-7.20 \\
(-1.16)\end{array}$ \\
\hline $\mathrm{B}+$ & $\begin{array}{c}2.49 \\
(1.62)\end{array}$ & $\begin{array}{c}1.36 \\
(0.83)\end{array}$ & $\begin{array}{c}18.17 * * * \\
(4.77)\end{array}$ \\
\hline B & $\begin{array}{l}2.31^{*} \\
(1.79)\end{array}$ & $\begin{array}{c}1.23 \\
(0.94)\end{array}$ & $\begin{array}{c}3.43 \\
(1.22)\end{array}$ \\
\hline B- & $\begin{array}{c}-0.15 \\
(-0.12)\end{array}$ & $\begin{array}{c}0.43 \\
(0.35)\end{array}$ & $\begin{array}{l}5.38 * * \\
(2.20)\end{array}$ \\
\hline $\mathrm{CCC}+$ & $\begin{array}{c}0.89 \\
(0.64)\end{array}$ & $\begin{array}{c}0.68 \\
(0.49)\end{array}$ & $\begin{array}{c}-0.95 \\
(-0.41)\end{array}$ \\
\hline $\mathrm{CCC}$ & $\begin{array}{c}-0.16 \\
(-0.11)\end{array}$ & $\begin{array}{c}0.94 \\
(0.62)\end{array}$ & $\begin{array}{c}-0.20 \\
(-0.07)\end{array}$ \\
\hline CCC- & $\begin{array}{c}-2.21 \\
(-1.29)\end{array}$ & $\begin{array}{c}-2.40 \\
(-1.46)\end{array}$ & $\begin{array}{c}-4.45 \\
(-1.41)\end{array}$ \\
\hline $\mathrm{CC}$ to $\mathrm{C}$ & $\begin{array}{l}-5.65 * * \\
(-1.98)\end{array}$ & $\begin{array}{c}-8.08 * * \\
(-2.62)\end{array}$ & $\begin{array}{c}7.84 * * * \\
(2.72)\end{array}$ \\
\hline
\end{tabular}

Table continues next page 


\begin{tabular}{|c|c|c|c|}
\hline $\begin{array}{l}\text { Hypothesis 1A. Are managers selling before } \\
\text { default? }\end{array}$ & \multicolumn{3}{|c|}{$\underline{\bar{\delta}_{\mathrm{B}}^{\mathrm{l}}}$} \\
\hline Bank Managers $\bar{\delta}_{\mathrm{B}}^{\mathrm{BANK}} \leq 0$ & $-10.81 * * *$ & $-3.80 * *$ & $-14.34 * * *$ \\
\hline Nonbank Managers $\bar{\delta}_{\mathrm{B}}^{\text {NONBANK }} \leq 0$ & 0.32 & 0.06 & -0.37 \\
\hline $\begin{array}{l}\text { Hypothesis } 1 B \text {. Who is more responsive before } \\
\text { default? }\end{array}$ & \multicolumn{3}{|c|}{$\bar{\delta}_{\mathrm{B}}^{\text {BANK }}-\bar{\delta}_{\mathrm{B}}^{\text {NONBANK }}$} \\
\hline $\begin{array}{l}\text { Bank Managers vs Nonbank Managers } \\
\bar{\delta}_{\mathrm{B}}^{\text {BANK }}-\bar{\delta}_{\mathrm{B}}^{\text {NONBANK }} \leq 0\end{array}$ & $-11.13^{* * *}$ & $-3.87 * *$ & $-13.97 * * *$ \\
\hline Borrower Fixed Effects & Yes & Yes & Yes \\
\hline Year and Month Time Effects & Yes & Yes & Yes \\
\hline Number Observations & 92,340 & 61,934 & 30,406 \\
\hline Number of Borrowers & 244 & 233 & 102 \\
\hline $\mathrm{R}^{2}$ & 0.26 & 0.30 & 0.27 \\
\hline
\end{tabular}

Notes: The table summarizes the regression estimates of the investment ratio specification defined by equation (2). The sample is limited only to a balanced panel of borrowers that had a 12-month history before and after default. This regression specification does not include CLO deal fixed effects because they are correlated with the bank and non-bank indicators. The regression panel was estimated using a GLS feasible approach that accounts for borrower clustered error heteroskedasticity (Cameron and Miller 2015). The hypothesis tests panel presents the average value of the maintained hypothesis with its corresponding F-value significance. The null hypotheses of $\bar{\delta}_{\mathrm{B}}^{\imath} \leq 0$ or $\bar{\delta}_{\mathrm{B}}^{\imath}-\bar{\delta}_{\mathrm{B}}^{\kappa} \leq 0$ are accepted when the values are negative and statistically significant. When the values are positive and statistically significant the null is rejected in favor of the alternative. The symbols $\left(^{*}\right),\left(^{* *}\right)$, and $(* * *)$ indicated statistical significance at the 10-, 5-, and 1-percent level. 
Table 6. Evidence from borrowers without any loan relationships

$$
\begin{aligned}
& \mathrm{R}_{\mathrm{tij}}=\alpha_{\mathrm{i}}+\alpha_{\mathrm{t}}+\beta_{1} \mathrm{x}_{\mathrm{tij} \bullet}^{\mathrm{B}}+\beta_{2} \mathrm{x}_{\mathrm{tij} \bullet}^{\mathrm{CLO}}+\sum_{\mathrm{h}=-12}^{12} \delta_{\mathrm{h}}^{\mathrm{M}} \operatorname{Rel}_{\mathrm{tij}, \mathrm{h}}^{\mathrm{M}}+\sum_{\mathrm{h}=-12}^{12} \delta_{\mathrm{h}}^{\mathrm{P}} \operatorname{Rel}_{\mathrm{tij}, \mathrm{h}}^{\mathrm{P}}+\sum_{\mathrm{h}=-12}^{12} \delta_{\mathrm{h}}^{\mathrm{U}} \mathrm{Re}_{\mathrm{tij}, \mathrm{h}}^{\mathrm{U}}+ \\
& \sum_{\mathrm{h}=-12}^{12} \delta_{\mathrm{h}}^{\mathrm{N}-\mathrm{BANK}} \mathrm{NORel}_{\mathrm{tij}, \mathrm{h}}^{\mathrm{BANK}}+\sum_{\mathrm{h}=-12}^{12} \delta_{\mathrm{h}}^{\mathrm{h}-\mathrm{NONBANK}} \operatorname{NORel}_{\mathrm{tij}, \mathrm{h}}^{\mathrm{NONBNK}}+\varepsilon_{\mathrm{tij}} \text {. }
\end{aligned}
$$

\begin{tabular}{|c|c|}
\hline Explanatory Variables & Balanced 12-month Panel \\
\hline Log(POSITION) & $\begin{array}{c}\text { 73.11*** } \\
(101.66)\end{array}$ \\
\hline \%ISSUE_OWNED & $\begin{array}{c}-2.64 * * * \\
(-27.30)\end{array}$ \\
\hline MATURITY & $\begin{array}{c}-1.53 * * * \\
(-4.98)\end{array}$ \\
\hline US _FIRM & $\begin{array}{c}-9.27 * * * \\
(-2.89)\end{array}$ \\
\hline EQUITY_REL & $\begin{array}{c}17.16^{* * * *} \\
(8.59)\end{array}$ \\
\hline CLO Balance & $\begin{array}{c}-0.03 * * * \\
(-25.31)\end{array}$ \\
\hline AAA to BBB- & $\begin{array}{c}-3.30 \\
(-0.83)\end{array}$ \\
\hline BB+ & $\begin{array}{c}20.32^{* * *} \\
(3.55)\end{array}$ \\
\hline BB & $\begin{array}{l}-7.79 * \\
(-1.91)\end{array}$ \\
\hline BB- & $\begin{array}{c}13.18^{* * *} \\
(6.14)\end{array}$ \\
\hline $\mathrm{B}^{+}$ & $\begin{array}{c}2.33 \\
(1.50)\end{array}$ \\
\hline B & $\begin{array}{l}2.20^{*} \\
(1.69)\end{array}$ \\
\hline B- & $\begin{array}{c}-0.29 \\
(-0.24)\end{array}$ \\
\hline $\mathrm{CCC}+$ & $\begin{array}{c}0.66 \\
(0.46)\end{array}$ \\
\hline CCC & $\begin{array}{c}-0.56 \\
(-0.36)\end{array}$ \\
\hline CCC- & $\begin{array}{l}-2.06 \\
(-1.20)\end{array}$ \\
\hline $\mathrm{CC}$ to $\mathrm{C}$ & $\begin{array}{c}-6.09 * * \\
(-2.12)\end{array}$ \\
\hline
\end{tabular}

Dependent variable: Borrower investment ratio $\mathrm{R}_{\mathrm{tij}}$ (percent) 


\section{Hypothesis 1A. Are managers selling before default?}

Manager-arranger relationships $\bar{\delta}_{\mathrm{B}}^{\mathrm{M}} \leq 0$

Managers with participant relationships $\bar{\delta}_{\mathrm{B}}^{\mathrm{P}} \leq 0$

Bank managers without relationships $\bar{\delta}_{\mathrm{B}}^{\mathrm{N}-\mathrm{BANKS}} \leq 0$

Nonbank managers without relationships $\bar{\delta}_{\mathrm{B}}^{\mathrm{N} \text {-NONBANKS }} \leq 0$

Managers with underwriter relationships $\bar{\delta}_{\mathrm{B}}^{\mathrm{U}} \leq 0$

Hypothesis 1B. Who is more responsive before default?

Manager-arranger vs banks without relationships

$\bar{\delta}_{\mathrm{B}}^{\mathrm{M}}-\bar{\delta}_{\mathrm{B}}^{\mathrm{N}-\mathrm{BANK}} \leq 0$

Manager-arranger vs nonbanks without relationships

$\bar{\delta}_{\mathrm{B}}^{\mathrm{M}}-\bar{\delta}_{\mathrm{B}}^{\mathrm{N}-\mathrm{NONBANK}} \leq 0$

Without relationships: bank vs nonbank $\bar{\delta}_{\mathrm{B}}^{\mathrm{N}-\mathrm{BANK}}-\bar{\delta}_{\mathrm{B}}^{\mathrm{N}-\mathrm{NONBANK}} \leq 0$

Post-Default Response

Manager-arranger relationships, $\bar{\delta}_{A}^{M}$

Bank managers without relationships, $\bar{\delta}_{A}^{\mathrm{N}-\mathrm{BANK}}$

Nonbank managers without relationships, $\bar{\delta}_{\mathrm{A}}^{\mathrm{N}-\mathrm{NONBANK}}$

\begin{tabular}{l|c}
\hline Borrower Fixed Effects & Yes \\
Year and Month Time Effects & Yes \\
Number Observations & 92,340 \\
Number of Borrowers & 244 \\
$\mathrm{R}^{2}$ & 0.26 \\
\hline \hline
\end{tabular}

Notes: The regression presents the regression estimates of the investment ratio regression model formally defined by equation (3). The specification focuses on the borrowers without existing loan relationships with CLO managers and underwriters. The sample is limited only to a balanced panel of borrowers that had 12-month history before and after default. This regression specification does not include CLO deal fixed effects because they are correlated with the bank and non-bank indicators. The regression panel model was estimated using a GLS feasible approach that accounts for borrower clustered error heteroskedasticity (Cameron and Miller 2015). The hypothesis tests panel presents the average value of the maintained hypothesis with its corresponding F-value significance. The null hypotheses of $\bar{\delta}_{\mathrm{B}}^{\mathrm{l}} \leq 0$ or $\bar{\delta}_{\mathrm{B}}^{\mathrm{\imath}}-\bar{\delta}_{\mathrm{B}}^{\kappa} \leq 0$ are accepted when the values are negative and statistically significant. When the values are positive and statistically significant the null is rejected in favor of the alternative. The symbols $(*),\left(^{* *}\right)$, and $(* * *)$ indicated statistical significance at the 10- 5-, and 1-percent level. 
Figure 1. Secondary Loan Trading Prices Before and After Default

(Price at Default $=100)$

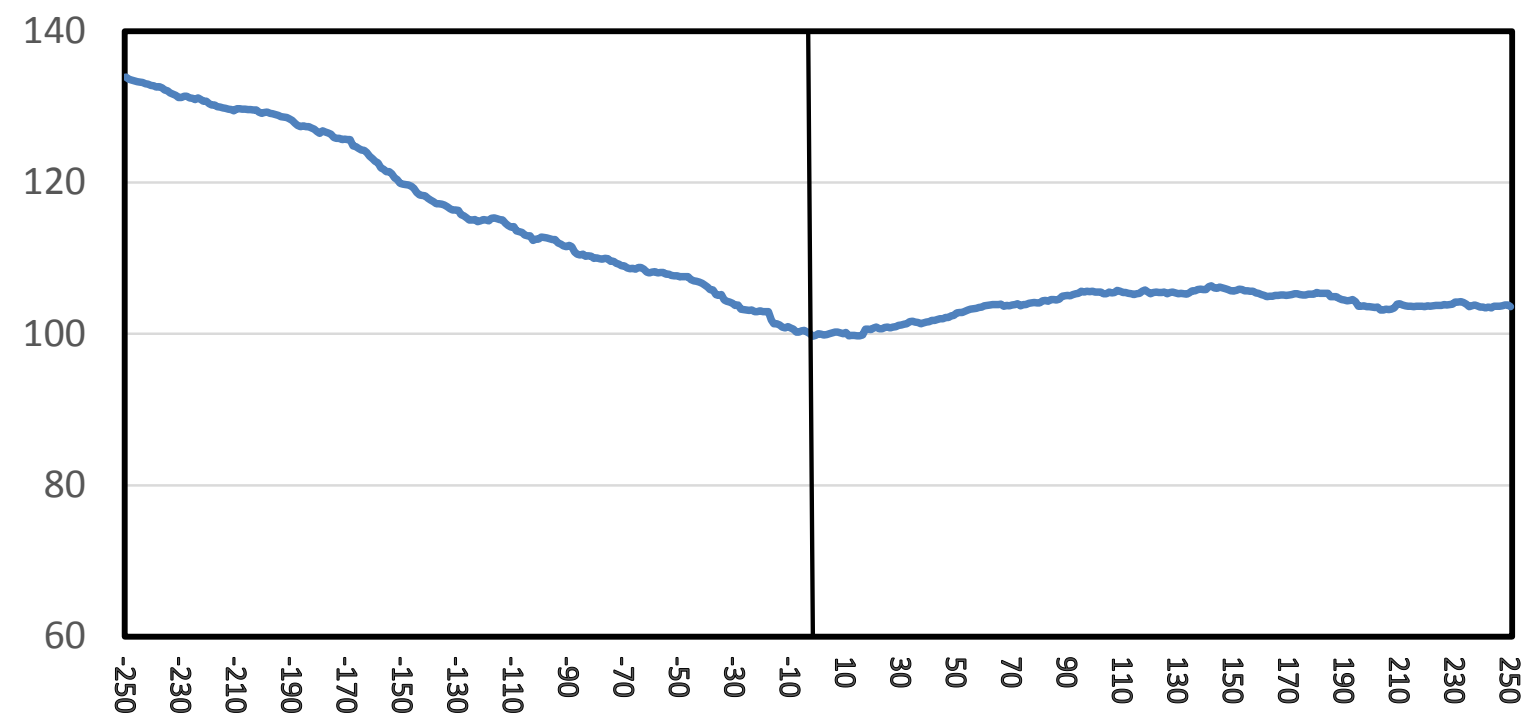

Trading Days From Default

Notes: This figure plots the average secondary loan price before and after default. Source: The Loan Syndications and Trading Association (LSTA). 
Figure 2. CLO average investment ratio $\mathrm{R}_{\mathrm{t}}$ by collateral manager type

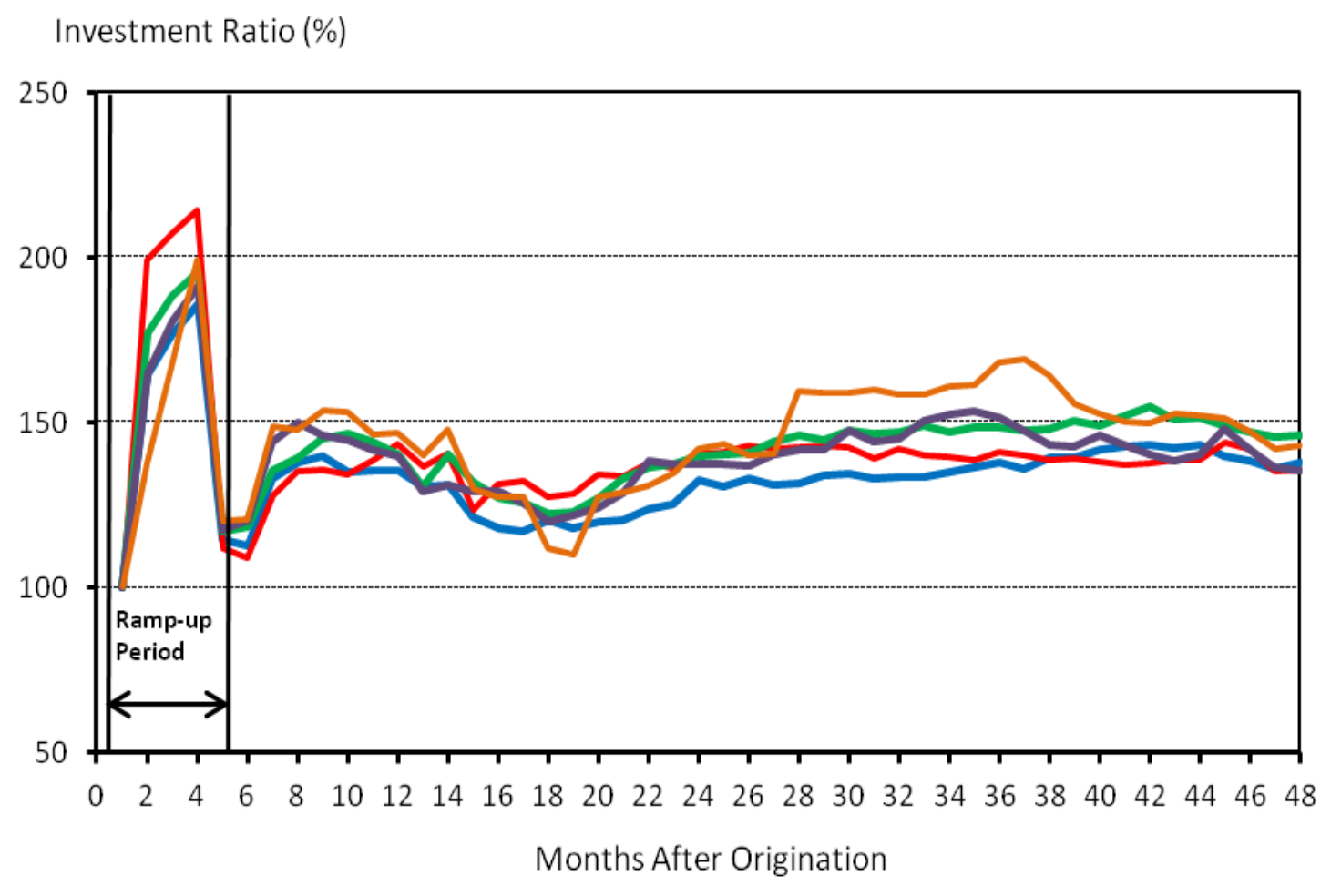

-Bank — Hedge Fund -Asset Manager —PE Firm —Insurance Firm

Notes: The figure traces the average investment ratio position held by collateral manager type for the first 4 years of the life of the CLO. 
Figure 3. Predicted investment ratio $\hat{\mathrm{R}}_{\mathrm{h}}^{\mathrm{h}}$ before and after default by relationship type

Investment Ratio (\%)
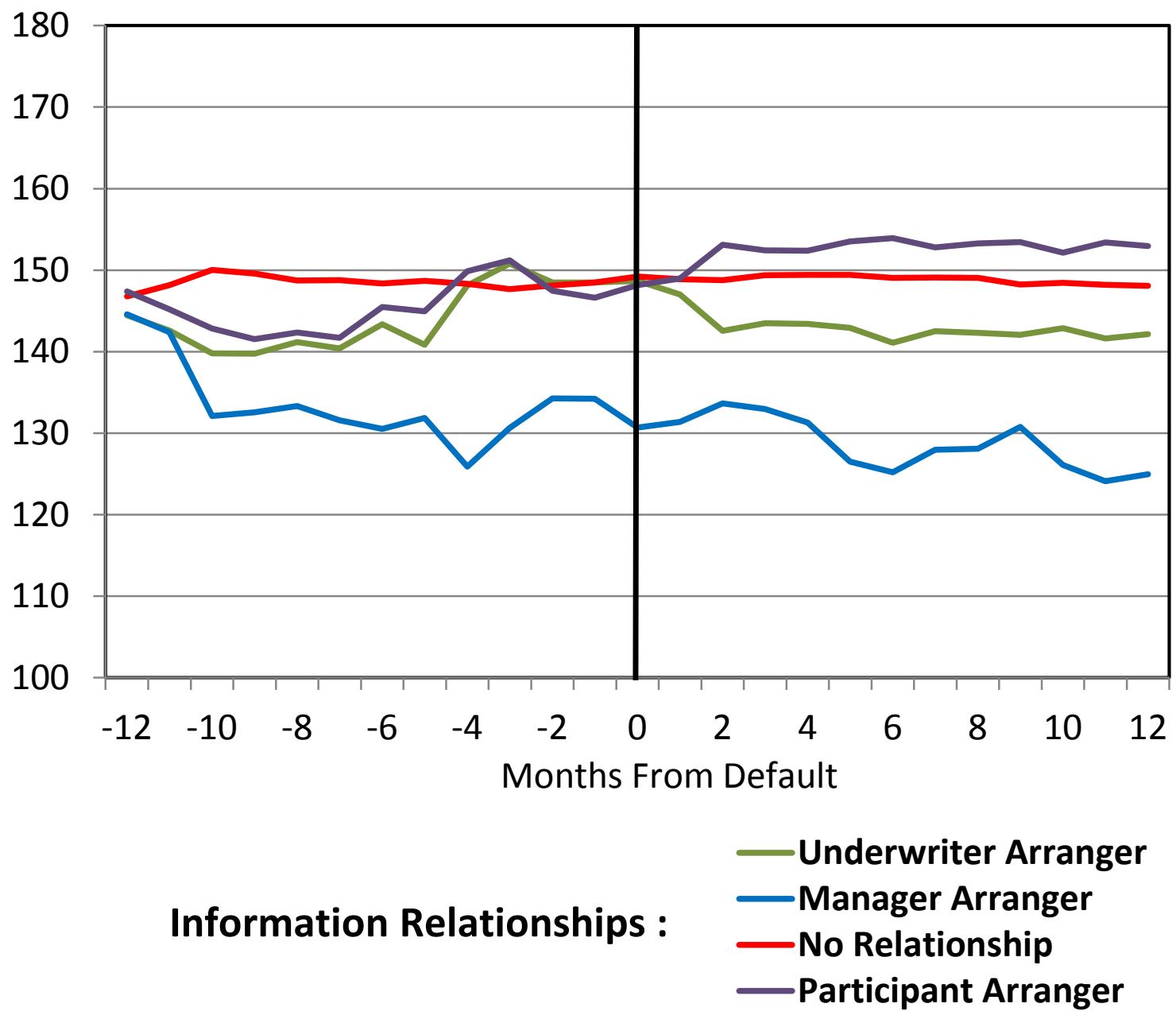

Notes: The figure traces the regression predicted investment ratio around default by the managerunderwriter relationship types. The prediction traces the investment ratio for the sample average for each relationship type defined by $\hat{\mathrm{R}}_{\mathrm{h}}^{\mathrm{l}}=\bar{\alpha}_{\mathrm{i}}+\bar{\alpha}_{\mathrm{t}}+\hat{\beta}_{1} \overline{\mathrm{x}}^{\mathrm{B}}+\hat{\beta}_{2} \overline{\mathrm{x}}^{\mathrm{CLO}}+\hat{\delta}_{\mathrm{h}}^{\mathrm{l}}=\hat{\mu}+\hat{\delta}_{\mathrm{h}}^{\mathrm{l}}$ (see equation 1). 